\title{
지속가능발전목표(SDGs)와 인권기반 개발협력
}

목 차

\section{I. 들어가면서}

II. 지속가능발전목표(SDGs)와 인권

1. SDGs 정의와 내용

2. UN 2030 의제 문서에 언급된 인권

3. SDGs와 인권의 연계

4. SDGs에 대한 인권관점에서의 평가

III. 인권기반접근(HRBA) 개발협력

1. 인권기반접근 $(\mathrm{HRBA})$ 의 정의와 개념

2. 인권기반접근(HRBA)의 특성

3. 인권기반접근(HRBA) 실행원칙: PANEL

IV . 지속가능발전목표(SDGs) 이행과 인권 연계

1. 이행 단계에 따른 인권 연계 방식

2. 목표에 따른 인권 연계 방식

3. 이행 주체에 따른 인권 연계 방식

V. 전망

참고문헌 


\section{요 약}

본 원고는 2015년 9월 세계연합(United Nations, UN) 총회가 채택한 지속가능개발 목표(Sustainable Development Goals, SDGs)를 내용과 의의를 인권의 관점에서 분석하고 SDGs 이행에서 인권기반접근(Human Rights Based Approach, HRBA) 을 적용하는 방법에 대해 모색한 시론적 성격의 글이다. '그 누구도 소외되지 않을 것 (leaving no one behind)'를 주창한 UN 2030 의제는 개도국과 선진국 모두를 대상으 로 하는 보편적 성격을 지닌다. 이는 ‘모든 사람의 모든 인권' (All human rights for all)을 추구하는 인권의 정신과 부합한다. 17 개 SDGs 모두가 직간접적으로 인권과 연관이 있고 대다수 목표의 내용에 인권이 담겨있다.

사회, 경제 환경의 조화 통합을 추구하는 지속가능발전과 거버넌스와 국제협력이 포함된 SDGs는 인권의 불가분성과 상호의존성 원칙과도 조응하고 있다. 따라서 SDGs 와 인권은 내용과 형식 모든 면에서 긴밀히 연계되어 있다고 할 수 있다.

본고는 제 2장에서 SDGs의 정의와 특성 그리고 내용과 구조를 설명하고 이어 제 3장에서 SDGs가 인권과의 관계를 직접 언급, 구조적 이해 및 SDGs에 대한 인권적 평가 등 다양한 측면에서 살펴본다.

제 4장에서는 국제개발협력 분야에서의 $\mathrm{HRBA}$ 의 개념과 특성을 설명하고 PANEL -Participation(참여), Accountability(책무성), Non-discrimination(비차별), Empowerment(자력화) \& Link to Human Rights Standards(인권기준과의 연계) - 원칙 중 인권기준과의 연계를 국제인권조약을 중심으로 설명하였다. 그리고 결론에 해당하는 제 5장에서 SDGs의 효과적 이행을 위해서는 인권의 주류화와 $\mathrm{HRBA}$ 가 필수적이라는 전제하에 지속가능발전목표(SDGs) 이행과 인권을 연계하는 방식을 이행 단계, 목표 및 이행 주체에 따라 구분하여 제시하였다. 


\section{I. 들어가며}

본 원고는 2015년 9월 세계연합(United Nations, 이하 UN) 총회가 채택한 지속가능개발목 표(Sustainable Development Goals, 이하 SDGs)1)를 인권의 관점에서 분석하고 SDGs 이행에 인권기반접근(Human Rights Based Approach, 이하 HRBA)을 적용하는 방법 모색 한 시론적 성격의 글이다.

한국의 경우 SDGs 시대를 맞이하여 과거 새천년개발목표(Millennium Development Goals, $\mathrm{MDGs}$ )와 달리 개도국의 이행을 지원하는 국제이행 이외에 국내적으로 이행해야 하는 이중의 과제를 안고 있다. 2011년 부산 세계개발원조총회가 국제개발협력 분야의 국제규범을 새롭게 규정한 것이었다면 2015년 UN의 2030 지속가능발전 의제(이하 2030 의제)는 국제사회가

제I장 국제개발협력을 통해 공동으로 성취해야 할 목표를 제정했다고 할 수 있다. 즉 SDGs가 달성해 야 할 무엇(what)이라면 효과적 개발협력을 위한 부산 글로벌파트너십(Global Partnership for Effective Development Cooperation, GPEDC)2)은 국제개발협력으로서 어떻게(how) 에 대한 것이라고 할 수 있다.

부산 총회의 주최국이었으며 SDGs가 채택되었던 2015년 당시 UN 경제사회이사회(Economic and Social Council, ECOSOC)와 인권이사회(Human Rights Council, 이하 HRC) 의장국 을 동시에 수임했던 한국 정부는 그 어느 나라보다도 SDGs를 인권, 성평등, 평화 등 국제사회의 보편적 가치와 원칙에 부합하게 모범적으로 이행할 책무를 지니고 있다. 게다가 2015년 당시 반기문 UN 사무총장이 한국인이었다는 사실은 그러한 책무성의 의미를 더 크게 만들고 있다.

본고 제 2장에서 SDGs가 인권과의 관계를 직접 언급, 구조적 이해 및 SDGs에 대한 인권적 평가 등 다양한 측면에서 살펴본다. 제 3 장에서는 국제개발협력 분야에서의 $\mathrm{HRBA}$ 의 개념과 특성을 설명하고 PANEL 원칙 중 인권기준과의 연계를 국제인권조약을 중심으로 설명하였다. 그리고 결론에 해당하는 제 4장에서 SDGs의 효과적 이행을 위해서는 인권의 주류화와 HRBA 가 필수적이라는 전제하에 SDGs 이행과 인권을 연계하는 방식을 이행 단계, 목표 및 이행 주체에 따라 구분하여 제시하였다.

1) 국내에서는 SDGs에 대해 지속가능발전목표와 지속가능개발목표 두 가지 번역어가 동시에 사용되고 있다. 전자는 환경부에서 사용하는 용어이고 후자는 외교부와 KOICA에서 사용하는 용어이다. 전자는 국내이행을 후자는 개도국에 대한 지원 즉 국제적 이행을 강조할 때 사용한다. 번역어의 차이는 개발(開發)과 발전(發展)에 대한 이해의 차이에서 기인하기도 한다. 참고로 일본도 우리처럼 두 번역어를 병행해 사용하고 $\mathrm{UN}$ 의 공식어인 중국어에서는 발전으로 번역한다. UN 2030 지속가능발전 의제와 SDGs 전체에 대한 한국어 번역은 외교부 비공식 번역본, 환경부 그리고 시민사회단체(KoFID) 번역본이 있다. 시민사회단체는 국내이행과 국제이행 모두를 고려하여 보다 포괄적인 개념인 지속가능발전목표 번역어를 사용한다. 본고는 국내이행과 국제이행 모두를 다루기에 지속가능발전 번역어를 사용한다. 본문에 인용한 2030 의제와 SDGs 한국어 번역은 시민사회 번역본을 저자가 일부 수정한 것이다.

2) 부산글로벌파트너십(GPEDC)에 대한 자세한 사항은 다음에서 확인 가능하다. http://effectivecooperation.org/ (접속일: 2017.12.05) 


\section{II. 지속가능발전목표(SDGs)와 인권}

SDGs는 지속가능발전의 언어를 사용하고 있지만 거의 모든 내용이 인권과 연관된다고 할 수 있다. 즉 SDGs는 명시적으로 인권 프레임을 사용하지 않았지만 내용에서 인권을 다루고 있다. 구체적으로 SDGs에서 인권은 비전과 원칙, 준수해야 할 규범, 달성해야할 목표 그리고 이행 수단 등 다양한 방식으로 다루어졌다.

\section{SDGs 정의와 내용}

지속가능발전목표(SDGs)란 2015년 9월 25일 UN 총회가 채택한 2030 지속가능발전 의제 (이하 2030 의제)3)에 담긴 17 개 목표(goal)와 169 개 세부목표(target)를 말한다. 각 목표는 최소 5 개 최대 19 개의 세부목표를 포함하고 있다. 이행수단인 17 번 목표를 제외한 16 개 목표는 달성해야 할 실체적 목적과 이를 이행하는 수단 성격의 세부목표로 구성되어 있다. 실체적 목표는 모두 112 개 그리고 17 번 목표의 19 개 세부목표를 포함한 수단 성격의 목표는 모두 57 개이다.

〈표 1〉지속가능발전목표(SDGs) 17개 목표 및 세부목표

\begin{tabular}{|c|c|c|}
\hline 핵심 단어 & 목표 제목 & $\begin{array}{l}\text { 세부목표 } \\
\text { (목적+수단) }\end{array}$ \\
\hline 빈곤 & 목표1. 모든 형태의 빈곤을 모든 지역에서 종식시킨다. & $7(5+2)$ \\
\hline 기아 & $\begin{array}{l}\text { 목표2. 기아를 종식하고, 식량안보를 확보하며 영양상태를 개선하며 } \\
\text { 지속가능농업을 증진한다. }\end{array}$ & $8(5+3$ \\
\hline 건강 & 목표3. 모든 사람의 건강한 삶을 보장하고 웰빙(well-being)을 증진한다. & $13(9+4)$ \\
\hline 교육 & $\begin{array}{l}\text { 목표4. 모든 사람을 위한 포용적이고 형평성 있는 양질의 교육 보장 } \\
\text { 및 평생교육 기회를 증진한다. }\end{array}$ & $10(7+3)$ \\
\hline 성평등 & 목표5. 성평등 달성 및 여성, 여아의 역량을 강화한다. & $9(6+3)$ \\
\hline 물 & $\begin{array}{l}\text { 목표6. 모든 사람을 위한 식수와 위생시설 접근성 및 지속가능한 관리 } \\
\text { 를 확립한다. }\end{array}$ & $8(6+2)$ \\
\hline 에너지 & $\begin{array}{l}\text { 목표7. 모든 사람을 위한 저렴하고 신뢰할 수 있으며 지속가능한 현대 } \\
\text { 적인 에너지에의 접근을 확립한다. }\end{array}$ & $5(3+2)$ \\
\hline
\end{tabular}

3) 문서의 영어 공식 명칭은 'Transforming our World: UN 2030 Agenda for Sustainable Development' (A/RES/70/1)이다.

6 | 국제개발협력 


\begin{tabular}{|c|c|c|}
\hline 핵심 단어 & 목표 제목 & $\begin{array}{c}\text { 세부목표 } \\
\text { (목적+수단) }\end{array}$ \\
\hline 일자리 & $\begin{array}{l}\text { 목표8. 지속적, 포괄적, 지속가능한 경제성장을 촉진하며 생산적인 완전 } \\
\text { 고용과 모두를 위한 양질의 일자리를 증진한다. }\end{array}$ & $12(10+2)$ \\
\hline 산업화 & $\begin{array}{l}\text { 목표 9. 복원력이 있는 인프라시설을 구축하고, 포용적이고 지속가능 } \\
\text { 한 산업화를 진흥시키며 혁신을 장려한다. }\end{array}$ & $8(5+3)$ \\
\hline 불평등 & 목표10. 국가 내, 국가 간 불평등을 완화한다. & $10(7+3)$ \\
\hline 도시 & $\begin{array}{l}\text { 목표11. 포용적이고 안전하며 복원력 있고 지속가능한 도시와 인간 } \\
\text { 거주지를 조성한다. }\end{array}$ & $10(7+3)$ \\
\hline 생산소비 & 목표12. 지속가능한 소비 및 생산 양식을 확립한다. & $11(8+3)$ \\
\hline 기후변화 & 목표13. 기후변화와 그 영향에 대처하는 긴급 행동을 시행한다* & $5(3+2)$ \\
\hline 해양 & $\begin{array}{l}\text { 목표14. 지속가능한 발전을 위한 해양, 바다, 해양자원을 보존하고 지 } \\
\text { 속가능하게 사용한다. }\end{array}$ & $10(7+3)$ \\
\hline 육상 & $\begin{array}{l}\text { 목표15. 육상 생태계를 보호, 복원 및 지속가능하게 이용하고, 산림을 } \\
\text { 지속가능하게 관리 하며, 사막화를 방지하고, 토지 황폐화를 } \\
\text { 막고 생물 다양성 감소를 억제한다. }\end{array}$ & $12(9+3)$ \\
\hline 거버넌스 & $\begin{array}{l}\text { 목표16. 지속가능발전을 위해 평화롭고 포용적인 사회를 건설하고, } \\
\text { 사법 정의에 대한 접근성을 제공하며, 모든 차원에서 효과적 } \\
\text { 이고 신뢰할 수 있는 포용적인 제도를 구축한다. }\end{array}$ & $12(10+2)$ \\
\hline 이행수단 & $\begin{array}{l}\text { 목표17. 이행수단 강화 및 지속가능발전을 위한 글로벌 파트너십을 } \\
\text { 확대한다. }\end{array}$ & 19 \\
\hline \multicolumn{2}{|r|}{ 목표 17개 } & $\begin{array}{l}\text { 세부목표 169개 } \\
\quad(112+57)\end{array}$ \\
\hline
\end{tabular}

출처: UN (2015) 바탕으로 저자 재구성

$\mathrm{SDGs}$ 에 대해 2030 의제 문서는 스스로를 헌장, 의제 및 행동계획 세가지 방식으로 정의 내리고 있다.

첫째는 2030 의제 제 51항은 SDGs를 '사람과 지구를 21세기 헌장(A charter for people and planet in the 21stcentury)'으로 정의하였다. 여기서 헌장이라는 의미를 부여한 의미는 1945년 20세기 중반에 채택한 UN 헌장을 비유한 것이다. UN 헌장과 2030 의제 모두 UN 총회가 채택하였다. 그러나 20세기 중반인 1945년 채택된 UN 헌장이 UN 회원 국가를 위한 것이라면 21세기 초인 2015년 채택한 2030 의제는 국가를 넘어 인민과 지구환경을 위한 기본적 규범이라고 할 수 있다.

둘째, 2030 의제 문서 제 52항은 SDGs를 '인민의, 인민에 의한, 인민을 위한 의제(An agenda of the people, by the people and for the people)'로 소개하고 있다. 이 문구는 
미국의 링컨 대통령의 유명한 1863년 게티즈버그 연설(Gettysburg Address)에서 인용한 것이다. 이를 오늘날의 표현으로 풀어보면 2030 의제가 전세계 시민을 위한 것이고 시민의 참여에 의해 만들어졌고 시민이 주체가 되어 이행하는 의제라는 의미이다.

셋째, 2030 의제 문서 전문에서는 SDGs를 '사람과 지구와 번영을 위한 행동계획(A plan of action for people, planet and prosperity)'으로 정의하였다. 여기서 사람, 지구, 번영은 지속가능발전의 세가지 축인 사회개발, 경제개발 및 환경을 의미한다. 즉 단순히 선언문에 그치 는 것이 아니라 구체적인 실천 행동을 의미한다.

〈표 2〉 2030 의제에 대한 UN의 정의

\begin{tabular}{l|l}
\hline \multicolumn{1}{c|}{ 구분 } & \multicolumn{1}{c}{ 정의 } \\
\hline 헌장 & $\begin{array}{l}\text { 사람과 지구를 21세기 헌장 (2030 의제 51항) } \\
\text { A charter for people and planet in the 21stcentury }\end{array}$ \\
\hline 의제 & $\begin{array}{l}\text { 인민의, 인민에 의한, 인민을 위한 의제 (2030 의제 52항) } \\
\text { An agenda of the people, by the people and for the people }\end{array}$ \\
\hline 행동계획 & $\begin{array}{l}\text { 사람과 지구와 번영을 위한 행동계획 (전문) } \\
\text { A plan of action for people, planet and prosperity }\end{array}$ \\
\hline
\end{tabular}

출처: UN (2015) 바탕으로 저자 재구성

SDGs는 2030 의제 문서의 일부로 2030 의제는 SDGs의 채택 배경과 맥락, 특성과 의의 그리고 후속 이행과 모니터링 제도와 절차에 대한 설명을 담고 있다.

〈표 3〉 UN 2030 지속가능발전 의제의 목차와 구조

\begin{tabular}{|c|c|c|}
\hline 구분 & 내용 & 항목 \\
\hline Preamble 서문 & \multicolumn{2}{|c|}{$\begin{array}{l}\text { People, Prosperity, Planet, Peace and Partnership 인간, 번영, 지구환경, } \\
\text { 평화, 파트너십 }\end{array}$} \\
\hline \multirow{8}{*}{$\begin{array}{l}\text { Declaration } \\
\text { 선언(1-53) }\end{array}$} & Introduction 머리말 & $1-6$ \\
\hline & Our Vision 우리의 비전 & $7-9$ \\
\hline & $\begin{array}{l}\text { Our shared principles and commitments 공통의 원칙과 약 } \\
\text { 속 }\end{array}$ & $10-13$ \\
\hline & Our world today 오늘날의 세계 & $14-17$ \\
\hline & The new agenda 새로운 의제 & $18-38$ \\
\hline & Means of implementation 이행 수단 & $39-46$ \\
\hline & Follow-up and review 후속과 검토 & $47-48$ \\
\hline & $\begin{array}{l}\text { A call for action to change our world 세계를 바꾸는 위한 } \\
\text { 행동 요청 }\end{array}$ & $49-53$ \\
\hline
\end{tabular}




\begin{tabular}{|c|c|c|c|}
\hline 구분 & & 내용 & 항목 \\
\hline \multirow{11}{*}{$\begin{array}{l}\text { Sustainable } \\
\text { Development } \\
\text { Goals and targets } \\
\text { 지속가능발전 } \\
\text { 목표와 세부목표 } \\
\text { (54-59) }\end{array}$} & \multicolumn{2}{|c|}{$\begin{array}{l}\text { Sustainable Development Goals and targets } \\
\text { 지속가능발전목표와 세부목표 }\end{array}$} & $54-58$ \\
\hline & \multicolumn{2}{|c|}{ SDG 1-15 and Targets 세부목표 } & 59 \\
\hline & \multicolumn{2}{|c|}{ SDG 16-10 Targets 세부목표 } & 59 \\
\hline & \multicolumn{2}{|c|}{ SDG 17 Targets 세부목표 } & 59 \\
\hline & \multicolumn{2}{|l|}{ Finance 재원 } & $17.1-17.5$ \\
\hline & \multicolumn{2}{|l|}{ Technology 기술 } & 17.6 \\
\hline & \multicolumn{2}{|c|}{ Capacity-building 역량강화 } & 17.9 \\
\hline & \multicolumn{2}{|l|}{ Trade 무역 } & $17.10-17.12$ \\
\hline & \multirow{3}{*}{$\begin{array}{l}\text { Systemic Issues } \\
\text { 시스템 이슈 }\end{array}$} & $\begin{array}{l}\text { Policy and Institutional Coherence 정 } \\
\text { 책 및 제도적 일관성 }\end{array}$ & $17.13-17.15$ \\
\hline & & $\begin{array}{l}\text { Multi-stake holder partnerships 다자 } \\
\text { 간 이해관계자 파트너십 }\end{array}$ & $17.16-17.17$ \\
\hline & & $\begin{array}{l}\text { Data, monitoring and accountability } \\
\text { 데이터, 모니터링 및 책무성 }\end{array}$ & $17.18-17.19$ \\
\hline \multicolumn{3}{|c|}{$\begin{array}{l}\text { Means of implementation and the Global Partnership 이행수단과 글로벌 파트너십 } \\
(60-71)\end{array}$} & $60-71$ \\
\hline \multirow{4}{*}{\multicolumn{2}{|c|}{$\begin{array}{l}\text { Follow-up and review } \\
\text { 후속과 검토 } \\
\text { (72-91) }\end{array}$}} & Follow-up and review 후속과 검토 & $72-77$ \\
\hline & & National level 일국적 차원 & $78-79$ \\
\hline & & Regional level 지역적 (대륙) 차원 & $80-81$ \\
\hline & & Global level 글로벌 차원 & $82-91$ \\
\hline
\end{tabular}

출처: UN (2015) 바탕으로 저자 재구성

SDGs는 2030년까지 향후 15년간 달성해야 할 목표로 채택되었다. 2012년부터 시민사회 포함 다양한 이해관계자가 'Post-2015 개발의제' 과정에 참여하였고4) 2014년부터 근 2년간의 정부간 협상을 통해 UN 총회에서 만장일치 결의안으로 채택되었다. 따라서 모든 $\mathrm{UN}$ 회원국은 2030년까지 SDGs 실현을 위해 노력하고 협력해야 하는 정치적 책무를 지닌다.

SDGs의 형식은 이전의 MDGs를 기본으로 하되 내용은 2012년 UN 리우+20 지속가능발전 국제회의(UN Conference on Sustainable Development, 이하 UNCSD)의 결과를 주축으 로 구성되었다.5) 그리고 2015년 7월 열린 아디스아바바 제 3차 개발재원회의 결과인 아디스

4) Post 2015 개발의제 수립 과정에 대한 자세한 사항은 다음을 참조하기 바란다. https://sustainabledevelopment. un.org/post2015 (접속일: 2017.12.05)

5) $\mathrm{UN}$ 지속가능발전국제회의(UNCSD)에 대한 자세한 사항은 다음을 참조하기 바란다. https://sustainabledevelopment. 
아바바 행동계획(Addis Ababa Action Agenda, AAAA)6)가 17번 목표의 이행수단에, 2015 년 12월 파리에서 열린 UN 기후변화협약(UN Framework Convention on Climate Change, 이하 UNFCCC) 제 21 차 당사국 회의의 결과7)가 13 번 목표에 포함되었다.

17 개의 SDGs는 지속가능발전의 3개 축인 사회발전, 경제개발과 환경 목표(1-15번)와 거버 넌스16번) 그리고 이행수단과 이행 시스템과 관련된 목표(17번)로 구성되어 있다. UN 은 이를 People, Prosperity, Planet, Peace, Partnership 다섯 개의 P로 설명한다. 1-15번 목표가 성취해야 할 목적(what)이라면 17번 목표는 이를 성취하는 수단(how)에 해당한다. 그리고 16 번 목표는 자체가 목적이자 동시에 1-15번 목표에 대한 수단이라는 이중적 성격을 지니고 있다.

〈표 4〉지속가능발전목표(SDGs)의 구조

\begin{tabular}{|c|c|c|c|}
\hline \multirow{2}{*}{ 분야별 과제와 목표 } & 사회발전 People & 경제개발 Prosperity & 환경 Planet \\
\hline & 1-6번 목표 등 & $6-12$ 목표 등 & 13-15 목표 등 \\
\hline 거버넌스 Peace & \multicolumn{3}{|c|}{ 16번 목표 (평화, 인권, 민주주의, 반부패 등) } \\
\hline $\begin{array}{c}\text { 이행수단 } \\
\text { Partnership }\end{array}$ & \multicolumn{3}{|c|}{$\begin{array}{l}\text { 17번 목표 } \\
\text { 이행수단 (재원, 무역, 기술, 역량강화) } \\
\text { 시스템 관련 이슈 (정책 및 제도적 일관성, 다자간 파트너십, 데이터와 모니터링) }\end{array}$} \\
\hline
\end{tabular}

출처: UN (2015) 바탕으로 저자 재구성

\section{2030 의제 문서에 언급된 인권}

$\mathrm{UN} 2030$ 의제 문서에서 인권은 전문, 소개(3항), 비전(8항), 공통의 원칙과 약속(10항), 새로운 의제(19항, 20항, 29항 및 35항), SDGs 세부목표(4.7), 이행수단과 글로벌 파트너십 (67항), 후속 및 검토(74항)에서 모두 10번 넘게 명시적으로 언급되었다. 인권이 일반 명사로 언급되기도 하지만 세계인권선언, UN 발전권 선언, 기업과 인권 이행원칙 (UNGPs), 아동권리 협약(67항) 등 특정 국제인권규범이 구체적으로 언급되기도 했다.

먼저 UN 2030 의제 전문에서는 'SDGs가 모든 인권의 실현과 성평등 달성, 그리고 모든 여성과 소녀들의 자력화를 추구한다'라고 선언하고 '통합적이고, 불가분하며, 지속가능 발전의

un.org/rio20 (접속일: 2017.12.05)

6) 아디스아바바 행동계획(AAAA)에 대한 자세한 사항은 다음을 참조하기 바란다. https://www.un.org/esa/ ffd/ffd3/ index.html (접속일: 2017.12.05)

7) UN기후변화협약(UNFCCC) 제21차 당사국 회의에 대한 자세한 사항은 다음을 참조하기 바란다. http://unfccc.int/ meetings/paris_nov_2015/session/9057.php (접속일: 2017.12.05) 
세 차원인 경제, 사회, 환경의 균형을 이룬다'고 언급하고 있다.

이어 본문의 서문 제 3항에서 '우리는 지금으로부터 2030년 사이에, 모든 곳에서 빈곤과 기아를 퇴치하고, 국가 내와 국가 간의 불평등과 싸우고, 평화롭고 공정하고 포용적인 사회를 건설하며, 인권을 보호하고 성평등 및 여성과 소녀의 자력화를 증진시키고, 지구와 그 천연자원을 지속시키기 위한 보호기제를 확립하리라 다짐한다'며 인권 목표의 핵심 내용임을 강조하였다.

더 나아가 비전을 다루는 제 8항에서 '우리는 인권과 인간의 존엄, 법치, 정의, 평등과 비차별 에 대한 보편적 존중, 인종·민족성·문화다양성에 대한 존중 및 인간 잠재력의 완전한 실현을 가능하게 하고 공동번영에 기여하는 평등한 기회가 있는 세상, 아이들에게 투자하며 모든 아이 가 폭력과 착취 없이 성장하는 세상, 모든 여성·소녀가 완전한 양성평등을 향유하고 그들의 인권 신장에 대한 모든 법적·사회적·경제적 장벽이 제거된 세상, 가장 취약한 계층의 필요가 충족되면서 공정하고 공평하며 관용하는 개방되고 사회적으로 포용적인 세상을 기대한다'며 인권의 2030 의제가 실현하고자 하는 비전의 주요 원칙임을 천명하고 있다. 한편 후속과 검토 (Follow-up and Review)를 다룬 제 74항에서도 인권을 모니터링 과정에서 인권을 중요한 원칙으로 강조하였다. ${ }^{8)}$

이를 토대로 2030 의제는 공통의 원칙과 약속을 다룬 제 10 항에서 구체적으로 1948 년 세계인 권선언과 이후 제정된 다양한 국제 인권조약 그리고 1986년 UN 발전권을 준수해야 할 규범적 기준으로 제시하였다.9) 그리고 SDGs의 특성을 소개한 새로운 의제 장의 제 19항에서 다시 세계인권선언과 국제인권법을 강조하였다.10)

이어 2030 의제는 제 20항에서 성평등 관련하여 인권을 강조하고11) 제 29항에서는 이주민의

8) 제 74항 (e): 동 과정은 인간중심적이고 성 인지적이며, 인권을존중하고최빈곤층, 가장 취약한 계층 그리고 가장 뒤처진 사람들에게 특히 초점을 맞출 것이다.

9) 제 10 항 이 새로운 의제는 국제법에 대한 완전한 존중을 포함하여 UN헌장의 목적과 원칙을 따른다. 이것은 세계인권선 언,국제인권조약, 새천년선언 및 2005년 세계정상회의 결과에 기반을 두고 있다. 이는 UN 발전권에 관한 선언과 같은 다른 문서들을 고려한다.

10) 제 19항 우리는 세계인권선언과 국제인권법과 다른 국제법과 관련된 기타 국제문서들의 중요성을 재확인한다. 우리는 $\mathrm{UN}$ 헌장에 따라 인종, 피부색, 성, 언어, 종교, 정치적 또는 기타의 의견, 민족적 또는 사회적 출신, 재산, 출생, 장애 또는 기타의 신분에 의한 어떠한 종류의 차별도 없이 모든 사람의 인권과 기본적 자유를 존중·보호·증진할 모든 국가들의 책임을 강조한다.

11) 제 20 항. 성평등 및 여성·소녀 권익신장의 실현은 모든 목표와 세부목표들의 진전에 결정적인 기여를 할 것이다. 인류의 절반이 계속해서 완전한 인권과 기회를 거부당한다면 인간의 완전한 잠재력과 지속가능개발의 달성은 불가능 하다. 여성과 소녀들은 양질의 교육, 경제적 자원 및 정치적 참여에 대한 평등한 접근뿐 아니라 남성·소년들과 평등한 고용·리더십 및 모든 수준에서의 의사결정 기회를 향유해야 한다. 우리는 지구·지역·국가 차원에서 성 격차 해소 및 양성평등과 여성 권익신장 관련 제도 지원 강화에 대한 투자를 현저히 확대하기 위해 노력할 것이다. 여성·소녀에 대한 모든 형태의 차별과 폭력은 남성·소년의 참여 등을 통해 철폐될 것이다. 이 의제의 이행에 있어 성 인지적 관점의 체계적인 주류화는 중요하다. 
인권을 강조하였다.12) 그리고 16 번 목표를 소개하면서 다시 발전권을 포함한 인권 존중을 사법 적 정의와 거버넌스에서 핵심 과제로 소개하였다.13)

SDGs 자체에서는 인권이 유일하게 세부목표 4.7에서 세계시민의식과 연계되어 인권교육으 로 포함되었다. 세부목표 4.7은 이외에 지속가능발전교육(Elucation for Sustainable Development, $\mathrm{ESD}$ ), 지속가능소비 교육, 성평등, 평화, 문화다양성에 대한 교육 등이 포함하 고 있다.14)

한편 이행수단과 글로벌 파트너십에서 민간기업의 SDGs 참여 관련하여 제67항에서는 2011 년 UN HRC가 만장일치로 채택한 UNGPs과 1990년 채택된 아동권리협약(Convertion on the Rights of the Child, $\mathrm{CRC}$ )을 기업이 준수해야 할 규범으로 구체적으로 명시되었다.15)

\section{SDGs와 인권의 연계}

17 개의 SDGs 가운데 $1-15$ 번 목표는 인권의 전통적 범주에서 경제사회문화 및 환경적 권리 를 다룬 것이라면 16 번 목표는 시민정치적 권리와 민주주의에 대한 권리를 다루었다고 할 수 있다. 예를 들어 건강을 다루는 3 번 목표는 건강권, 교육을 다루는 4 번 목표는 교육권, 식수를

12) 제 29항. 우리는 포용적 성장과 지속가능개발을 위한 이주민들의 긍정적인 기여를 인식한다. 우리는 또한 국제이주가 출신국·경유국·목적국의 개발과 중대한 관련성이 있으며 일관적이고 포괄적인 대응을 요구하는 다차원적인 현실 이라는 점을 인식한다. 우리는 인권의 완전한 존중 및 (체류자격에 상관없이) 이주민 그리고 난민·피난민에 대한 인도적 대우를 수반한 안전하고 질서 있는 정규 이주를 보장하기 위해 국제적으로 협력할 것이다. 그러한 협력은 또한 난민을 수용하는 공동체(특히 개도국 내)의 회복력을 강화할 것이다. 우리는 이주민들이 자신의 국적국으로 귀환할 권리를 강조하며, 국가들이 귀환하는 자국민들을 적절한 절차에 따라 수용해야 한다는 점을 상기한다.

13) 제 35항. 지속가능발전은 평화와 안보 없이 실현될 수 없으며, 평화와 안보는 지속가능개발 없이는 위험에 처할 것이다. 이 새로운 의제는 정의에 대한 평등한 접근을 제공하고 인권(발전권 포함) 존중과 모든 차원에서의 효과적인 법치·모범적 거버넌스(good governance) 및 투명하고 효과적이며 책임 있는 제도에 기초하는 평화롭고 공정하며 포용적인 사회 건설의 필요성을 인식한다. 본 의제는 불평등, 부패, 열악한 거버넌스 및 불법 자금·무기 거래와 같이 폭력·불안·불의를 야기하는 요소들을 다루고 있다. 우리는 분쟁의 해결·예방 및 평화구축·국가건설 관련 여성의 역할 보장 등을 통한 분쟁 후 국가 지원 노력을 배가해야 한다. 우리는 식민·외국 점령 하에 있는 사람들의 경제·사회 개발과 환경에 지속적으로 부정적 영향을 미치는 완전한 자결권 실현의 장애요인을 제거하는데 국제법에 따라 더욱 효과적인 방법과 행동을 취할 필요가 있다

14) 세부목표 4.7. 2030년까지 지속가능개발 교육과 지속가능한 생활방식, 인권, 성평등, 평화와 비폭력의 문화 증진, 세계시민의식, 문화적 다양성 및 문화의 지속가능개발 기여에 대한 공감을 위한 교육 등을 통하여 모든 학습자가 지속가능개발 촉진에 필요한 지식과 기술을 획득하도록 보장한다.

15) 제 67항. 민간기업 활동과 투자. 혁신은 생산성, 포용적 경제성장 및 고용창출의 주요한 동력이다. 우리는 영세기업부 터 협동조합, 다국적기업에 이르는 민간부문의 다양성을 인정한다. 우리는 모든 기업이 창의성과 혁신을 지속가능개발 과제의 해결에 적용할 것을 요구한다. 우리는 역동적이고 제대로 기능하는 기업 부문을 조성하는 한편, 기업과 인권 이행 지침(UNGPs), 국제노동기구의 노동기준, 아동권리협약(CRC) 및 주요 다자 환경 협정과 같은 관련 국제 기준.협정 및 이에 관한 기타 진행 중인 구상에 따라 당사국들의 노동권과 환경.보건 기준을 보호할 것이다. 
다루는 6 번은 물에 대한 권리라고 말할 수 있다. 17 번 목표는 발전권, 국제연대, 민주적 국제질 서, 인권지표 등과 연계되어 있다.

이 이외에도 인권으로 명시하지 않았지만 인권의 핵심적 가치이자 원칙인 성평등 (목표 5), 불평등 (목표 10), 법치와 정의 (16.3), 알권리 (세부목표 16.10), 차별 (세부목표 16.12) 등과 관련된 목표와 세부목표가 있다.16)

〈표 5〉 지속가능발전목표(SDGs)와 국제인권기준 연계17)

\begin{tabular}{|c|c|c|}
\hline 핵심 단어 & 지속가능발전목표 (SDGs) & 국제 인권기준 (예시) \\
\hline 1. 빈곤 & 목표 1. 모든 형태의 빈곤을 모든 지역에서 종식시킨다. & $\begin{array}{l}\text { 세계인권선언 22, 25, } \\
\text { 사회권 규약 }\end{array}$ \\
\hline 2. 기아 & $\begin{array}{l}\text { 목표 2. 기아를 종식하고, 식량 안보를 확보하며 영양 } \\
\text { 상태를 개선하며 지속가능 농업을 증진한다. }\end{array}$ & $\begin{array}{l}\text { 세계인권선언 25, } 28 \\
\text { 사회권 규약 (ICESCR) }\end{array}$ \\
\hline 3. 건강 & $\begin{array}{l}\text { 목표 3. 모든 사람의 건강한 삶을 보장하고 웰빙(well- } \\
\text { being)을 증진한다. }\end{array}$ & $\begin{array}{l}\text { 세계인권선언 } 3,25,27,28 \\
\text { 사회권 규약 }\end{array}$ \\
\hline 4. 교육 & $\begin{array}{l}\text { 목표 4. 모든 사람을 위한 포용적이고 형평성 있는 양 } \\
\text { 질의 교육 보장 및 평생교육 기회를 증진한다. }\end{array}$ & $\begin{array}{l}\text { 세계인권선언 26, } 28 \\
\text { 사회권 규약 }\end{array}$ \\
\hline 5. 성평등 & 목표 5. 성평등 달성 및 여성, 여아의 역량을 강화한다. & $\begin{array}{l}\text { 세계인권선언 } 2 \\
\text { 사회권 규약 } \\
\text { 여성차별철폐협약(CEDAW) } \\
\text { 아동권리협약(CRC) }\end{array}$ \\
\hline 6. 물 & $\begin{array}{l}\text { 목표 6. 모든 사람을 위한 식수와 위생시설 접근성 및 } \\
\text { 지속가능한 관리를 확립한다. }\end{array}$ & $\begin{array}{l}\text { 세계인권선언 } 25, \\
\text { 사회권 규약 } \\
\text { 물에 대한 권리 선언 }\end{array}$ \\
\hline 7. 에너지 & $\begin{array}{l}\text { 목표 7. 모든 사람을 위한 저렴하고 신뢰할 수 있으며 } \\
\text { 지속가능한 현대적인 에너지에의 접근을 확립 } \\
\text { 한다. }\end{array}$ & $\begin{array}{l}\text { 세계인권선언 25, } 27 \\
\text { 사회권 규약 }\end{array}$ \\
\hline 8. 일자리 & $\begin{array}{l}\text { 목표 8. 지속적, 포괄적, 지속가능한 경제성장을 촉진 } \\
\text { 하며 생산적인 완전 고용과 모두를 위한 양질 } \\
\text { 의 일자리를 증진한다. }\end{array}$ & $\begin{array}{l}\text { 세계인권선언 } 4, \\
\text { 사회권 규약 } \\
\text { ILO 핵심노동기준 }\end{array}$ \\
\hline 9. 산업화 & $\begin{array}{l}\text { 목표 9. 복원력이 있는 인프라시설을 구축하고, 포용적 } \\
\text { 이고 지속가능한 산업화를 진흥시키며 혁신을 } \\
\text { 장려한다. }\end{array}$ & $\begin{array}{l}\text { 세계인권선언 } 19,25,27 \\
\text { 사회권 규약 }\end{array}$ \\
\hline 10. 불평등 & 목표 10. 국가 내, 국가 간 불평등을 완화한다. & $\begin{array}{l}\text { 세계인권선언 2, 21, } 22 \\
\text { 사회권 규약 } \\
\text { 발전권 선언 }\end{array}$ \\
\hline
\end{tabular}

16) KOICA에서는 이를 범분야(cross-cutting) 이슈라고 부른다.

17) 덴마크인권연구소(DIHR)은 SDGs 개별 세부목표와 연관된 국제인권기준을 조사해서 나열한 온라인 데이터베이스 를 구축하였다. (http://sdg.humanrights.dk) (접속일: 2017.12.05) 또한 <표 5>에서는 세부목표가 아닌 목표 차원에서 자주 언급되는 국제인권규범만 예시하였다. 


\begin{tabular}{|c|c|c|}
\hline 핵심 단어 & 지속가능발전목표 (SDGs) & 국제 인권기준 (예시) \\
\hline 11. 도시 & $\begin{array}{l}\text { 목표 11. 포용적이고 안전하며 복원력 있고 지속가능 } \\
\text { 한 도시와 인간 거주지를 조성한다. }\end{array}$ & $\begin{array}{l}\text { 세계인권선언 } 25, \\
\text { 사회권 규약 } \\
\text { UN HABITAT 신도시의제 } \\
\text { (New Urban Agenda, NUA) }\end{array}$ \\
\hline 12. 생산소비 & 목표 12. 지속가능한 소비 및 생산 양식을 확립한다. & $\begin{array}{l}\text { 세계인권선언 25(1) } \\
\text { 사회권 규약 }\end{array}$ \\
\hline 13. 기후변화 & $\begin{array}{l}\text { 목표 13. 기후변화와 그 영향에 대처하는 긴급 행동을 } \\
\text { 시행한다 }\end{array}$ & $\begin{array}{l}\text { 세계인권선언 25(1) } \\
\text { 사회권 규약 } \\
\text { UN 기후변화협약(UNFCCC) }\end{array}$ \\
\hline 14. 해양 & $\begin{array}{c}\text { 목표 14. 지속가능한 발전을 위한 해양, 바다, 해양자원 } \\
\text { 을 보존하고 지속가능하게 사용한 }\end{array}$ & $\begin{array}{l}\text { 세계인권선언 25(1), } \\
\text { 사회권 규약 }\end{array}$ \\
\hline 15. 육상 & $\begin{array}{l}\text { 목표 15. 육상 생태계를 보호, 복원 및 지속가능하게 } \\
\text { 이용하고, 산림을 지속가능하게 관리 하며, } \\
\text { 사막화를 방지하고, 토지 황폐화를 막고 생 } \\
\text { 물 다양성 감소를 억제한다. }\end{array}$ & $\begin{array}{l}\text { 세계인권선언 25(1) } \\
\text { 사회권 규약 }\end{array}$ \\
\hline 16. 거버넌스 & $\begin{array}{l}\text { 목표 16. 지속가능발전을 위해 평화롭고 포용적인 사 } \\
\text { 회를 건설하고, 사법 정의에 대한 접근성을 } \\
\text { 제공하며, 모든 차원에서 효과적이고 신뢰할 } \\
\text { 수 있는 포용적인 제도를 구축한다. }\end{array}$ & $\begin{array}{l}\text { 세계인권선언 3, 5, 6, 8, 19, } 21 \\
\text { 자유권 규약 (ICCPR) } \\
\text { 아동권리협약(CRC) } \\
\text { 고문방지협약 (CAT) } \\
\text { 인종차별철폐협약(ICERD) } \\
\text { 장애인권리협약 (CRPD) } \\
\text { 부패방지협약(UNCAC) }\end{array}$ \\
\hline 17. 이행수단 & $\begin{array}{l}\text { 목표 17. 이행수단 강화 및 지속가능발전을 위한 글로 } \\
\text { 벌 파트너십을 확대한다. }\end{array}$ & $\begin{array}{l}\text { 세계인권선언 } 12,27(1), 28, \\
\text { 발전권 선언 }\end{array}$ \\
\hline
\end{tabular}

한편 거버넌스를 다루는 SDG 16 번 목표는 평화, 민주주의, 인권 및 반부패 관련 세부목표 를 담고 있다. 특히 인권과 밀접한 연관이 있는 세부목표에는 법치와 사법정의(세부목표 16.3), 민주적 의사결정과 제도(16.6과 16.7), 정보접근권(알권리)과 기본적 자유(세부목표 16.10), 비차별(세부목표 16.b) 등이 있다. 그리고 취약계층으로 아동인권(16.2, 16.9)이 포함 되어 있다. 
〈표 6〉SDG 16번 목표의 12 개 세부목표와 인권 연계

\begin{tabular}{|c|c|c|}
\hline 핵심단어 & 세부목표 & $\begin{array}{c}\text { 국제인권기준 및 제도 } \\
\text { (예시) }\end{array}$ \\
\hline 폭력 & $\begin{array}{l}16.1 \text { 모든 곳에서 모든 형태의 폭력 및 관련 사망률을 } \\
\text { 상당히 감축 }\end{array}$ & $\begin{array}{l}\text { 시민정치적권리 국제규약 } \\
\text { (ICCPR) }\end{array}$ \\
\hline 아동폭력 & $\begin{array}{l}16.2 \text { 아동에 대한 학대, 착취, 매매 및 모든 형태의 폭력 } \\
\text { 과 고문 종식 }\end{array}$ & 아동권리협약(CRC) \\
\hline $\begin{array}{l}\text { 법치와 } \\
\text { 사법정의 }\end{array}$ & $\begin{array}{c}16.3 \text { 국가적 · 국제적 수준에서 법치를 증진하고, 모두에 } \\
\text { 게 정의에 대한 평등한 접근 보장 }\end{array}$ & $\begin{array}{l}\text { 시민정치적권리 국제규약 } \\
\text { (ICCPR) } \\
\text { 베니스위원회18) } \\
\text { 국제개발법기구(IDLO)19) }\end{array}$ \\
\hline 불법 범죄 & $\begin{array}{l}16.4 \text { 2030년까지 불법 자금 및 무기 유출입을 상당히 } \\
\text { 감축하고, 도난자산 회수 및 반환을 강화하며, 모든 } \\
\text { 형태의 조직범죄를 방지 }\end{array}$ & \\
\hline 부정부패 & 16.5 모든 형태의 부패 및 뇌물을 상당히 감축 & UN반부패협약(UNCAC) \\
\hline 민주적 제도 & $\begin{array}{l}16.6 \text { 모든 수준에서 효과적이고 책임 있으며 투명한 제 } \\
\text { 도 개발 }\end{array}$ & $\begin{array}{l}\text { 시민정치적권리 국제규약 } \\
\text { (ICCPR) }\end{array}$ \\
\hline $\begin{array}{l}\text { 민주적 } \\
\text { 의사결정 }\end{array}$ & $\begin{array}{l}16.7 \text { 모든 수준에서 반응하고, 포용적이고, 참여적이며, } \\
\text { 대표성 있는 의사결정 보장 }\end{array}$ & $\begin{array}{l}\text { 시민정치적권리 국제규약 } \\
\text { (ICCPR) }\end{array}$ \\
\hline $\begin{array}{l}\text { 글로벌 } \\
\text { 거버넌스 }\end{array}$ & 16.8 개도국의 국제 거버넌스 기관 참여를 확대하고 강화 & UN 발전권 선언 \\
\hline 아동인권 & $\begin{array}{l}16.9 \text { 2030년까지 출생신고를 포함하여 모두에게 법적 } \\
\text { 정체성 부여 }\end{array}$ & 아동권리협약(CRC) \\
\hline $\begin{array}{c}\text { 알권리 } \\
\text { (정보접근) }\end{array}$ & $\begin{array}{c}16.10 \text { 국내법과 국제협약에 따라 정보에 대한 대중의 } \\
\text { 접근을 보장하고 근본적 자유를 보호 }\end{array}$ & 열린정부파트너십(OGP)20) \\
\hline 국제협력 & $\begin{array}{r}\text { 16.a 모든 수준에서, 특히 개도국에서 폭력을 예방하고 } \\
\text { 테러리즘과 범죄에 대응하기 위한 역량을 배양하 } \\
\text { 도록 국제협력 등을 통하여 관련 국내 기관을 강화 }\end{array}$ & \\
\hline 비차별 & $\begin{array}{l}\text { 16.b 지속가능발전을 위한 비차별적 법과 정책을 증진하 } \\
\text { 고 시행 }\end{array}$ & $\begin{array}{l}\text { UN인권최고대표사무소 } \\
(\mathrm{OHCHR})\end{array}$ \\
\hline
\end{tabular}

출처: UN (2015) 바탕으로 저자 재구성

18) 전세계 헌법재판소 협의체인 베니스 위원회 (Venice Commission)에 대한 자세한 내용은 다음에서 확인가능하다. http://www.venice.coe.int/webforms/events/(접속일: 2017.12.05)

19) 법치를 목적으로 설립된 국제기구인 국제개발법기구(IDLO)에 대한 자세한 내용은 다음에서 확인가능하다. http://www.idlo.int/(접속일: 2017.12.05)

20) 정보공개를 목적으로 설립된 열린정부파트너십(OGP) 대한 자세한 내용은 다음에서 확인가능하다 https://www. opengovpartnership.org/(접속일: 2017.12.05) 
한편 재정, 기술, 무역 및 역량강화 네 요소로 포함한 이행수단(Means of Implementation, $\mathrm{MoI}$ )과 정책 및 제도적 일관성, 다자간 파트너십 및 데이터와 모니터링 세 요소를 포함한 시스템 관련 이슈(systemic issues)로 구성된 17번 목표 또한 도구로서의 인권과 밀접한 연관 이 있다. 네 가지 이행수단의 경우 HRBA가 요구되며 정책 및 제도적 일관성은 인권 주류화, 다자간 파트너십의 경우로 인권은 다양한 행위자의 공통 규범으로, 그리고 데이터와 모니터링의 경우 인권지표와 인권영향평가 등이 강조된다.

\section{〈표 7〉 17번 목표의 주요 세부목표}

\begin{tabular}{c|l}
\hline 17번 목표 & \multicolumn{1}{c}{ 세부 목표 } \\
\hline \multirow{4}{*}{ 이행수단 } & 재정 $(17.1-17.5)$ \\
\cline { 2 - 2 } & 기술 $(17.6-16.8)$ \\
\cline { 2 - 2 } & 역량강화 (17.9) \\
\cline { 2 - 2 } & 무역 (17.10-17.12) \\
\hline \multirow{4}{*}{ 시스템 관련 이슈 } & 정책 및 제도적 일관성 (17.13-17.15) \\
\cline { 2 - 2 } & 다자간 파트너십 (17.16-17.17) \\
\cline { 2 - 2 } & 데이터와 모니터링 (17.18-17.19) \\
\hline
\end{tabular}

출처: UN (2015) 바탕으로 저자 재구성

\section{3. 인권관점에서 본 SDGs 대한 평가}

의견 수렴과 협상과정에서 UN 인권기구와 국제 인권단체는 적극적 개입을 해왔고21) 그 결과 SDGs에 과거 MDGs에 비교해서 책무성 메커니즘이 강화되었고 인권이 상당부분 반영되 어 있다는 평가를 받고 있다. 전반적으로 이전의 MDGs에 비해 인권 측면이 양과 질에서 크게 개선되었다고 평가받고 있다.

\section{가. 긍정적 평가}

첫째, SDGs 제정 과정과 결과에 인권의 주요 원칙 - 보편성, 불가분성, 상호의존성 등이 적절히 반영되어 있다. SDGs는 모든 사람을 대상으로 하고 있으며(보편성), 경제사회문화 및 환경적 권리(1-15번)와 시민정치적 권리(16번)이 연계 통합되어 있고(불가분성) 그리고 지속가능발전과 평화, 민주주의, 인권, 거버넌스(16번)와의 상호연관성이 강조되고 있다. "그 누구도 소외되지 않을 것(leaving no one behind)'를 주창한 UN 2030 의제는 개도국과 선진

21) UN 인권기구인 UN인권최고대표사무소 $(\mathrm{OHCHR})$ 에서 SDGs 관련 발표한 성명서 및 관련 자료는 다음에서 확인가 능하다. http://www.ohchr.org/EN/Issues/MDG/Pages/The2030Agenda.aspx（접속일: 2017.12.05） 
국 모두를 대상으로 하는 보편적 성격을 지닌다. 이는 '모든 사람의 모든 인권(All human rights for all)'을 추구하는 인권의 정신과 부합한다.

둘째, 과정의 측면에서도 약 2-3년에 걸친 전세계적인 협의 과정을 통해 시민사회와 주요 이해관계자의 의견이 적지 않게 반영되었다. 즉 $\mathrm{HRBA}$ 에서 강조하는 참여의 원칙이 어느 정도 반영되었다고 볼 수 있다.

셋째, 인권교육이 세부목표로 기업과 인권 관련 규범이 명시적으로 언급되었다. 예를 들어, 인권교육은 세부목표 4.7 을 통해 세계시민교육 및 평화, 성평등, 소비자 교육과 연계할 수 있고 제 67항에 언급된 UN 기업과 인권 이행원칙(UN Guiding Principles on Business and Human Rights, 이하 UNGPs)와 UN 아동권리협약(Convention on the Rights of the Child, 이하 $\mathrm{CRC)}$ 은 기업의 인권적 책무성을 강화하는 계기로 활용할 수 있다.

\section{제I 장}

\section{나. 인권관점에서 본 SDGs의 한계}

첫째 법적 구속력 부재이다. 세계인권선언처럼 UN 총회에서 선언형식으로 채택하여 법적 구속력은 없기에 불이행에 대한 강제수단이 없다. 구체적인 이행이 개별 국가의 '자발성'에 의존하여 SDGs에 대한 해석과 이행 방식에 대한 자의적 해석과 왜곡 가능성이 있다.

둘째, 책무성이 여러 곳에서 언급되었지만 구체적 실행 메커니즘 없이 선언적 의미에 국한되 었다. 책무성을 구체적으로 실현하는 수단인 HRBA에 대한 명시적 언급이 없다.22) 특히 초국 적 기업 관련 국가의 역외관할의무(Extra-territorial Obligations ETO), 그리고 개발 관련 국제기구(세계은행 등)와 국제무역협정의 인권책무성에 대한 언급이 없는 것은 가장 큰 걸림돌 이다.

셋째, 이행 모니터링 관련 국제인권 메커니즘과의 연계 및 통합이 취약하다. 제네바에서 이루어 지고 있는 UN 인권기구의 이행 모니터링 제도 - 조약기구, 특별절차, 보편적정례검토(UPR) 등 외의 유기적 체계적 연계가 없다. 국내 차원에서도 국가인권정책기본계획(National Action Plan, 이하 NAP)와 SDGs 이행 계획과의 연계도 불분명하다. 따라서 같은 내용에 대해 인권과 $\mathrm{SDGs}$ 가 분절화된 방식으로 다루어지고 있다.

22) 이에 비해 2011년 부산 효과적 개발협력 글로벌 파트너십 제22항은 권리기반접근(RBA)을 시민사회단체의 주요한 역할과 과제로 명시했다. 22. 시민사회단체들은 국민들이 권리를 주장할 수 있도록 하고, 인권기반 접근을 활성화하며, 개발 정책 및 새로운 파트너십을 형성하고, 그 이행과정을 감독하는 중요한 역할을 한다. 시민사회단체들은 또한 국가가 제공하는 서비스에 보완되는 영역에서 서비스를 제공한다. 이에 대한 인식을 바탕으로 우리는 다음 사항을 이행할 것이다. 
〈표 8〉 인권과 SDGs 비교 - 규범, 제도 및 이행

\begin{tabular}{|c|c|c|}
\hline & 인권 & SDGs \\
\hline $\begin{array}{c}\text { 주요 } \\
\text { 국제규범 }\end{array}$ & $\begin{array}{l}\text { 세계인권선언(1948) } \\
\text { 9대 주요 인권조약(1965-현재) } \\
\text { 주요 인권관련 선언 } \\
\text { 발전권 선언(1986) } \\
\text { 비엔나 2차세계인권회의(1993) }\end{array}$ & $\begin{array}{l}\text { 스톡홀름 인간환경회의(1972) } \\
\text { 리우 환경회의(1992) } \\
\text { 코펜하겐 사회발전정상회의(1995) } \\
\text { Millennium Summit(2000) } \\
\text { 새천년개발목표(MDGs)(2002) } \\
\text { 리우+10(2002) } \\
\text { 리우+20(2012) } \\
\text { Addis Ababa Action Agenda(AAAA)(2015) } \\
\text { UN 2030 Agenda for SD(2015) } \\
\text { UNFCCC(2015) }\end{array}$ \\
\hline 주요 원칙 & 보편성, 상호불가분성, 상호의존성 등 & 포용성, 보편성, 변혁성, 통합성, 포괄성, 책무성 등 \\
\hline UN 사무국 & $\begin{array}{l}\text { UN인권최고대표사무소(OHCHR), } \\
\text { 제네바 }\end{array}$ & UN 경제사회국(DESA), 뉴욕 \\
\hline $\begin{array}{l}\mathrm{UN} \text { 이행 제도 } \\
\text { 및 절차 }\end{array}$ & $\begin{array}{l}\text { 9대 조약기구(Treaty Body) } \\
\text { 특별절차(Special Procedure) } \\
\text { 보편적정례검토(UPR) 포럼(소수자, } \\
\text { 사회권, 기업과 인권, 법치와 민주주의) }\end{array}$ & $\begin{array}{l}\text { UN 고위급정치포럼(HLPF) } \\
\text { 자발적국별보고(VNR) } \\
\text { UN 개발협력포럼(DCF) } \\
\text { UN 개발재원포럼(FfD Forum) } \\
\text { UN 전문기구 및 프로그램 }\end{array}$ \\
\hline $\begin{array}{l}\text { 국가간 갈등 } \\
\quad \text { 구도 }\end{array}$ & $\begin{array}{l}\text { 서구 - 비서구 } \\
\text { 선진국 - 개도국 }\end{array}$ & 선진국-개도국 \\
\hline $\begin{array}{l}\text { 국가별 이행 } \\
\quad \text { 보고 }\end{array}$ & $\begin{array}{l}\text { UPR(약 3시간, 4년반) } \\
\text { 개별 인권조약기구 } \\
\text { (약 9시간, 4-5년) }\end{array}$ & 자발적국별보고(VNR)(15분, 4년 마다) \\
\hline 시민사회 & NGO & $\begin{array}{l}\text { 9대 이해관계자 그룹(Major Group) - 노동, 농 } \\
\text { 민, 원주민, 아동청년, 여성, NGO, 과학기술, 기 } \\
\text { 업, 지자체 }\end{array}$ \\
\hline $\begin{array}{l}\text { 국제 이행보고 } \\
\text { 관련 } \mathrm{NGO} \\
\text { 역할 }\end{array}$ & $\begin{array}{l}\text { 사전 서면의견 제출 } \\
\text { 심의중 참관만(발언 기회 없음) } \\
\text { 권고안 채택회의 때 발언 가능 }\end{array}$ & $\begin{array}{l}\text { 사전 국내의견 수렴 및 반영 } \\
\text { 심의 중 발언 가능(2분) }\end{array}$ \\
\hline $\begin{array}{l}\text { 국내제도 - } \\
\text { 주무 부처 }\end{array}$ & $\begin{array}{l}\text { 법무부 } \\
\text { 국가인권정책협의회 }\end{array}$ & $\begin{array}{l}\text { 환경부(국내 이행) } \\
\text { 외교부(국제 및 개도국 이행 지원) } \\
\text { UN Development Assistance Framework(DAF) } \\
\text { 개도국 경우 }\end{array}$ \\
\hline $\begin{array}{c}\text { 국내 제도 - } \\
\text { 위원회 } \\
\end{array}$ & 국가인권위 (독립) & $\begin{array}{l}\text { 지속가능발전/ SDGs 위원회? } \\
\text { (대통령/국무총리 산하) }\end{array}$ \\
\hline 국내정책 & $\begin{array}{l}\text { 3차 국가 인권정책기본계획(NAP) } \\
\text { (2017-2022) }\end{array}$ & $\begin{array}{l}\text { SDGs 이행 국가행동계획(NAP)(2018-2030) } \\
\text { 수립 예정 }\end{array}$ \\
\hline $\begin{array}{c}\text { 주요 시민사회 } \\
\text { 전략 }\end{array}$ & Naming \& Shaming & $\begin{array}{l}\text { 직접 실행(Service delivery) } \\
\text { Naming \& Shaming } \\
\text { 거버넌스 참여 } \\
\text { 파트너십 참여 }\end{array}$ \\
\hline
\end{tabular}

출처: UN 고위급정치포럼(HLPF) 인권최고대표사무소(OHCHR) 홈페이지를 토대로 저자 재구성 


\section{III. 인권기반접근(HRBA) 개발협력23)}

\section{1. 인권기반접근(HRBA) 정의와 개념}

제 I 장

개

발

협

력

이

슈

제II장

제표장

$\mathrm{HRBA}$ 는 기본적으로 빈곤의 인권의 문제로 이해하고 더 나아가 인권침해로 적극적으로 해석하는데 기초하고 있다.

빈곤은 전통적으로 경제적 소득의 관점에서 이해되어 왔다. 대표적인 것이 1 인당 국내총생산 (GDP)이다. MDGs에서 사용하는 세계은행의 절대적 빈곤에 대한 기준은 실질구매력(PPP) 기준 하루 1.25 달러 미만이다. 빈곤을 이러한 소득의 관점에서 보면 빈곤 퇴치는 경제개발을 통한 소득의 증대를 의미한다. 이러한 빈곤에 대한 경제적 접근에 따르면 빈곤퇴치를 위해서는 소득이 증대되어야 하고 소득증대를 위해서는 경제가 성장해야 한다. 그리고 경제성장이 곧 개발로 이해되어졌다. 즉, 개발은 구체적으로 경제성장과 소득증대를 통한 빈곤퇴치를 의미로 이해되었다. 역으로 빈곤퇴치와 경제개발 또는 개발은 거의 같은 의미로 이해되었다.

그러나 경제성장 중심의 경제개발을 추진하여도 빈곤의 문제가 해결되지 못한다는 비판이 지속적으로 제기되었다. 또한 소득의 관점에서 빈곤감축을 위한 대응책을 취해도 본질적으로 빈곤이 해소되지 못한다는 인식이 확산되었다. 따라서 빈곤을 단순히 소득이 부족한 것 이상의 의미로 이해해야 한다는 주장이 등장하였다.

특히 1990년 UNDP의 인간발전보고서(Human Development Report, HDR)을 계기로 개발에 대한 인권적 이해 및 접근이 학자와 시민사회 및 UN 내에서 확산되기 시작하였다.

인도의 대표적인 개발경제학자인 아마티야 센(Amartya Kumar Sen)은 빈곤을 역량의 박탈로 이해하고 사회구조적 문제로 인식하는 역량 접근법을 제시하였다. 대표적인 국제 인권단

23) 자세한 사항은 '이성훈, '제 7장 인권.' 『국제개발협력 심화편』. 성남: 한국국제협력단'을 참조하기 바란다. 
체인 국제 엠네스티(Amnesty International)도 ‘빈곤을 인권침해’로 규정하고 인권문제로 접 근하기 시작하였다. 그리고 세계은행은 빈곤을 '직업, 생산수단 소유, 저축과 같은 물질적 재화 와 기회의 부족뿐만 아니라, 건강, 신체의 보전, 공포와 폭력으로부터의 자유, 사회적 소속감, 문화적 정체성, 조직력, 정치적 영향력을 행사할 능력, 그리고 존중 받고 존엄 있는 삶을 영위할 능력과 같은 신체적 및 사회적 재화의 부족 상태'로 이해하고 있다.

$\mathrm{UN}$ 의 사회권 위원회는 빈곤을 “적절한 생활수준과 시민적, 문화적, 경제적, 정치적, 사회적 권리를 향유하는데 필수적인 자원, 역량, 선택권, 안전, 권한 등이 지속적이고 만성적으로 박탈 된 인간의 조건"으로 정의하였다.

경제협력개발기구(Organization for Economic $\mathrm{Co}^{-}$operation and Development, 이하 OECD)의 개발원조위원회(Development Assistance Committee, DAC)는 2001년 4월에 채택 한 ‘DAC 빈곤감소 가이드라인'에서 아래 여섯 가지의 능력이 결여된 상태를 ‘빈곤’ 으로 정의하였다.

첫째, 경제적 능력으로 필요한 소비를 할 수 있고 자본을 보유할 수 있는 정도의 수입이 보장되지 않은 상태이다. 둘째, 인간적 능력으로 보건의료 서비스, 영양, 안전한 식수, 교육, 위생적인 환경이 보장되지 않은 상태이다. 셋째, 정치적 능력으로 개인의 인권이 인정되는 가운 데 정치·정책 과정에 참가하고 의사결정에 영향을 줄 수 있는 여건이 보장되지 않은 상태이다. 다섯째, 사회 문화적 능력으로 인간으로서 존엄을 유지하고 사회의 일원으로서 사회적 지위가 인정되는 여건이 보장되지 않은 상태이다. 여섯째, 보호 능력으로 식품부족, 질병, 재해, 범죄, 전쟁, 분쟁 등에 의한 취약성으로부터 스스로를 보호할 수 있는 여건이 보장되지 않은 상태이다. 그리고 젠더와 환경을 빈곤 관련 범분야 이슈로 제기하였다.

\section{〈표 9〉빈곤에 대한 인권적 접근과 정의}

\begin{tabular}{c|l}
\hline 학자 또는 기관 & 빈곤의 이해와 정의 \\
\hline 아마티야 센 & 빈곤은 권리의 박탈로 기본적 자유 즉 역량을 발휘하지 못하는 상태 \\
\hline & $\begin{array}{l}\text { 직업, 생산수단 소유, 저축과 같은 물질적 재화와 기회의 부족뿐만 아니 } \\
\text { 라, 건강, 신체의 보전, 공포와 폭력으로부터의 자유, 사회적 소속감, } \\
\text { 세계은행 } \\
\text { 문화적 정체성, 조직력, 정치적 영향력을 행사할 능력, 그리고 존중 받고 } \\
\text { 존엄 있는 삶을 영위할 능력과 같은 신체적 및 사회적 재화의 부족 상태 }\end{array}$ \\
\hline $\begin{array}{c}\mathrm{UN} \mathrm{사회권} \mathrm{규약} \\
\text { (CESCR) 위원회 }\end{array}$ & $\begin{array}{l}\text { 적절한 생활수준과 시민적, 문화적, 경제적, 정치적, 사회적 권리를 향유 } \\
\text { 하는데 필수적인 자원, 역량, 선택권, 안전, 권한 등이 지속적이고 만성적 } \\
\text { 인 박탈되는 인간의 조건 }\end{array}$ \\
\hline $\begin{array}{c}\mathrm{OECD} \mathrm{개발원조위원회} \\
\text { (DAC) }\end{array}$ & 경제적, 인간적, 정치적, 사회문화적 및 보호적 역량이 박탈된 상태 \\
\hline
\end{tabular}

출처:『국제개발협력 심화편』. 제 7장 
위에서 언급한 사례에서 보듯이 빈곤은 단순히 경제적 문제를 넘어서는 다차원적 현상으로 이해되고 있다. 빈곤 그 자체가 시급한 인권적 사안이며 무력화와 배제의 결과라고 볼 수 있는 것이다. 즉 빈곤은 인권 침해의 원인이자 결과이며 더 나아가 다른 인권 침해를 유발하는 조건이 기도 하다.

\section{2. 인권기반접근(HRBA)의 특성}

1990년대부터 본격적으로 사용하기 시작한 $\mathrm{HRBA}$ 는 단체와 지역에 따라 다양한 방식으로 전개되었다. 2003년 $\mathrm{HRBA}$ 를 실행하던 $\mathrm{UN}$ 기관은 $\mathrm{HRBA}$ 에 대한 개념과 원칙 및 적용 가이드라 인에 대한 본격적인 논의를 거쳐 2003년 HRBA에 대한 공통의 이해(common understanding) 에 합의하였다.

이 공통의 이해는 크게 세 개의 원칙과 13 개의 함의로 구성되어 있다. 3 개의 공통이해(UN Common Understanding on the Human Rights-Based Approach)에 합의를 이루었으며, 이를 통해 모든 개발협력 프로그램이 세계인권선언과 국제인권기제에 명시된 인권 실현을 증진 시켜야 하고, 모든 개발협력 프로그램에 인권 기준과 원칙들을 적용해야 하며, 의무부담자와 권리보유자의 역량을 개발하는데 기여해야 함을 확인하였다.

\section{〈상자 1〉 스템포드 공통이해(Common Understanding)}

1. 모든 개발 협력, 정책, 기술 지원의 프로그램들은 세계인권선언과 다른 국제 인권 장치들에 명시된 인권의 실현을 증진시켜야 한다.

2. 세계인권선언과 다른 국제 인권 문서에 담긴 기준과, 이로부터 도출되는 원칙들은, 모든 분야와 모든 개발협력 프로그래밍 과정의 단계에서 모든 개발협력과 프로그래밍을 이끌어야 한다.

3. 개발 협력은 '의무 부담자'가 자신들의 의무를 다하고, '권리 보유자'가 자신의 권리를 주장할 수 있는 역량을 향상하는데 기여하여야 한다.

출처: UN (2003)

스탬포드 공통이해는 HRBA의 특성으로 13가지를 제시하고 있다(UN, 2003).

(1) 참여하는 주민은 재화나 서비스의 수동적인 수혜자라기보다는, 자신 스스로의 발전에 있어 주요 행위자로서 인식해야 한다.

(2) 참여는 수단이자 목적이다.

(3) 전략은 사람들을 무력화(disempowering)가 아니라 자력화(empowering)한다.

(4) 결과와 과정 모두를 모니터링하고 평가한다.

(5) 분석에 모든 이해관계자를 포함한다. 
(6) 프로그램은 사회에서 소외되고, 혜택을 받지 못하고, 배제된 그룹들에 초점을 맞춘다.

(7) 현지 지역사회와 주민이 개발과정에서 주인의식을 가진다.

(8) 프로그램은 불균형/불평등(disparity) 감소를 목표로 한다.

(9) 시너지 효과를 위해서 하향식 그리고 상향식 접근 방법을 모두 사용한다.

(10) 빈곤퇴치/개발 관련 문제에 대한 상황분석을 통해 즉각적, 근본적 그리고 기본적인 원인들을 규명한다.

(11) 프로그래밍에서 측정 가능한 목표와 세부목표를 중요하게 다룬다.

(12) 전략적인 파트너십을 개발하고 유지한다.

(13) 프로그램은 모든 이해관계자들의 책무성을 지원한다.

위에서 제시한 특성은 이후 HRBA의 PANEL원칙과 프로그래밍에서 설명하도록 한다. 위 에서 언급한 $\mathrm{HRBA}$ 의 주요 특성을 다시 정리하면 아래와 같다.

첫째, $\mathrm{HRBA}$ 는 빈곤과 개발을 다루는 개념적 틀이다. 틀이란 영어로 Framework를 말한다. 프레임이란 사진을 구성하는 틀, 즉 액자를 말한다. 즉 어떤 틀을 선택하느냐에 따라 보이는 사진의 내용이 결정된다. 즉 자선, 욕구 및 $\mathrm{HRBA}$ 의 차이에서 설명했듯이 $\mathrm{HRBA}$ 는 인권 프레임으로 빈곤과 개발을 이행하고 평가하는 것을 말한다.

둘째, $\mathrm{HRBA}$ 는 빈곤과 개발 문제를 다루는 국제 규범이다. 빈곤과 개발은 전통적으로 국가의 정책적 문제로 다루어져 왔다. 민주적인 정부의 경우 국민 대다수의 의견을 반영한 복지정책으 로 다루어지는 반면, 권위주의 또는 독재정부의 경우 국민의 불만을 잠재우기 위한 시혜적 정책으로 나타나곤 한다. 그러나 HRBA에서 빈곤과 개발은 정당의 정치적 공약이나 정부의 정책을 넘어서서 국가가 가입한 국제인권조약과 $\mathrm{UN}$ 의 회원국가로서 지켜야 할 국제인권 규범 의 실천을 의미한다. 특히 국제개발협력은 빈곤 퇴치가 가난한 개도국 내부의 문제가 아니라 국가 간 협력의 문제이기에 해당 국가 모두에게 구속력을 지니는 국제인권규범이 중요하게 다루어진다.

따라서 국제인권규범에서 강조하는 인권의 보편성, 불가분성, 상호의존성, 비차별, 법치 등 중요한 인권원칙이 적용된다. 즉 국제개발협력에서 $\mathrm{HRBA}$ 는 관련된 국가와 이해관계자가 국제 인권법적 의무를 실행하는 규범적 행위라고 할 수 있다. 이에 대해 스탬포드 공통이해는 '모든 개발 협력, 정책, 기술 지원의 프로그램들은 세계인권선언과 다른 국제 인권 장치들에 명시된 인권의 실현을 증진시켜야 하고 그러한 국제인권규범에 따라 개발협력 프로그램을 기획 및 실행해야한다'고 강조하고 있다. 
셋째, $\mathrm{HRBA}$ 는 빈곤과 개발 문제를 다루는 전략이자 도구이다. 전략이자 도구로서의 $\mathrm{HRBA}$ 는 빈곤의 구조적 조건인 사회경제적 불평등과 참여적 개발을 저해하는 차별적 관행이나 불공정 한 권력의 분배를 시정하고자 한다. 이를 위하여 $\mathrm{HRBA}$ 는 빈곤과 개발을 정당한 권리를 보유한 개인과 집단(권리보유자) 그리고 그에 상응하는 의무를 가진 국가와 비국가 이해관계자(의무부 담자) 관계의 관점에서 파악한다. 그리고 권리의 실현을 위해 권리보유자와 의무부담자의 실행 역량 강화에 주력한다. 스탬포드 공통이해는 이에 대해 '개발 협력은 의무 부담자가 자신들의 의무를 다하고, 권리 보유자가 자신의 권리를 주장할 수 있는 역량을 향상하는데 기여하여야 한다'고 강조한다.

한편 전략으로서의 $\mathrm{HRBA}$ 는 빈곤퇴치와 개발의 과정 및 결과 모두 강조한다. 즉 $\mathrm{HRBA}$ 는 주민이 개발의 전 과정에 주인의식을 가지고 주체로 참여하는 참여적 개발을 강조하고 상향식과 하향식의 장점을 결합하는 것을 강조한다. 그리고 빈곤에 대한 상황분석을 통해 빈곤의 즉각적, 근원적, 구조적 원인을 규명하고 이를 바탕으로 한 프로그래밍에서 측정가능한 목표와 세부목표 를 설정하는 도구를 제공한다. 즉 $\mathrm{HRBA}$ 는 개발의 효과성을 효율적으로 제고하는데 유용한 전략과 도구의 역할을 한다.

\section{3. 인권기반접근(HRBA)의 실행 원칙: PANEL}

앞에서 소개한 스템포드 공통이해는 $\mathrm{HRBA}$ 에서 고려해야 할 인권 원칙으로 보편성과 양도불 가능성. 불가분성, 상호의존성과 상호연관성, 비차별과 형평성, 참여와 포용, 책무성과 법치를 강조하였다. 이후 UN OHCHR이 2005년 발간한 "빈곤감소 전략에 대한 인권적 접근 - 원칙과 가이드라인”은 참여(Participation), 책무성(Accountability), 비차별(Non-Discrimination), 자력화(Empowerment) 그리고 인권기준과의 연계(Linkages to human rights standards) 을 포함한 PANEL원칙을 제시하고 있다.24)

다섯 개의 PANEL원칙 가운데 마지막 인권기준과의 연계는 SDGs에 대한 HRBA와 밀접한 관련이 있다.

인권기준과의 연계(Link to Human Rights Standards)란 국내 및 국제적으로 승인 실행중 인 인권기준과 개발의 목표를 연계해서 법적 제도화하는 것을 의미 한다. HRBA는 국제인권의 주요 원칙에 기반하고 있기 때문에 인권 기준과의 연계는 앞에서 강조한 참여, 책무성, 자력화가

24) PANEL원칙은 이 다섯 가지 원칙과 특성의 영어 단어 첫 문자를 조합하여 만든 용어이다. 각 원칙에 대한 설명은

‘『국제개발협력 심화편』. 성남: 한국국제협력단. P.515-22를 참조하기 바란다. 
제도적으로 작동될 수 있도록 하는 것이다.

인권기준과의 연계에서는 인권에 대한 명시적 표명이 중요하게 강조된다. 인권 증진은 개발 의 결과이자 목적이기도 하다. 따라서 인권기준과의 연계는 단순히 개발목표를 인권과 연결하는 데 국한하지 않고 인권의 언어로 개발의 목표를 명시적으로 표명하는 것이다. 이러한 목적의식 적 행위는 개발 과정에 인권의 원칙을 보다 체계적으로 통합시키는데 매우 중요하다.

인권기준은 크게 국내적 기준과 국제적 기준으로 나눌 수 있으며 기준은 인권 규범과 제도를 포함하는 넓은 의미로 해석할 수 있다. 국내 인권 기준은 헌법의 기본권 조항과 인권 관련 법률과 규정, 그리고 판례 및 결정례를 말하고 국제적 기준은 국가가 비준한 국제인권조약과 국제관습법과 관련 제도를 말한다.

국제인권기준은 조약, 선언, 원칙, 가이드라인처럼 다양한 형식이 있으면 법적 구속력이 각각 다르다. 조약의 경우는 개별 국가의 비준을 거치기에 법적 구속력이 높고 이행을 감시하는 조약위원회가 구성된다. 그러나 선언 등 다른 규범은 법적 구속력이 없이 자발성에 의해 이행된 다. 한편 조약 이외에 1980대부터 만들어지기 시작한 특별절차(special procedures)25)와 2008 년부터 시행하기 시작한 $\mathrm{UPR} 26)$ 은 $\mathrm{UN} \mathrm{HRC}$ 의 대표적인 제도와 절차로 다양한 분야와 주제 및 인권취약계층의 인권보호와 증진에 큰 기여를 해오고 있다.

2015년 현재 국제인권법의 근간이 되는 국제인권조약은 모두 아홉 개이다. 1965년 남아공의 제도화된 인종차별 정책인 아파르트헤이트(apartheid)로 촉발된 전세계적인 인종차별 반대운 동을 계기로 첫 인권조약이 제정되었다. 이후 사회권과 자유권 국제규약이 이듬해인 1966년 채택되었고 이어서 지난 2007년 강제실종협약과 장애인권협약이 채택되었다. 현재 9 개의 인권 조약 이행을 감시하는 조약위원회가 설치 운영되고 있으면 조약 가입 당사국은 보통 4-5년 마다 국가보고서를 제출하고 심의를 받는다. 한국의 경우 이주노동자권리협약과 강제실종철폐 협약을 제외한 7 개의 국제인권조약에 가입하였다.

25) 2017 년 12 월 현재 44 개 주제별, 12 개 국가별 특별절차가 설립되었다. 12 개 국가에 아시아에서는 북한, 미얀마, 캄보디아가 포함되어 있다. 자세한 사항은 다음 홈페이지를 참조하기 바란다. http://www.ohchr.org/EN/ HRBodies/SP/Pages/Welcomepage.aspx(접속일: 2017.12.05)

26) 한국은 2008년 첫 보편적정례검토(UPR) 심의를 받았고 2012년에 이어 2017년 11월 세번 째 심의를 받았다. 자세한 사항은 다음 홈페이지를 참조하기 바란다. http://www.ohchr.org/EN/HRBodies/UPR/Pages/UPRMain.aspx (접속일: 2017.12.05) 
〈표 10〉 국제인권조약 현황

\begin{tabular}{|c|c|c|c|}
\hline 조약 공식명칭 (영문 및 한국어 약칭) & $\begin{array}{l}\text { 채택/발효 } \\
\text { 년도 }\end{array}$ & $\begin{array}{l}\text { 비준 당사국수 } \\
\text { (2015년 12월) }\end{array}$ & $\begin{array}{c}\text { 한국 } \\
\text { 가입 연도 }\end{array}$ \\
\hline $\begin{array}{l}\text { 경제적사회적문화적 권리에 관한 국제규약 } \\
\text { (ICESCR, 사회권 규약) }\end{array}$ & 1966년/1976년 & 164 & 1990년 \\
\hline 시민적정치적권리에 관한 국제규약(ICCPR, 자유권 규약) & 1966년/1976년 & 168 & 1990년 \\
\hline $\begin{array}{l}\text { 모든 형태의 인종차별 철폐에 관한 국제협약(ICERD, 인 } \\
\text { 종차별철폐협약) }\end{array}$ & 1965년/1969년 & 177 & 1979년 \\
\hline $\begin{array}{l}\text { 여성에 대한 모든 형태의 차별철폐에 관한 협약 } \\
\text { (CEDAW, 여성차별철폐협약) }\end{array}$ & 1979년/1981년 & 189 & 1985년 \\
\hline $\begin{array}{l}\text { 고문 및 그 밖의 잔혹한 비인도적인 또는 굴욕적인 대우 } \\
\text { 나 처벌의 방지에 관한 협약(CAT, 고문방지협약) }\end{array}$ & 1984년/1987년 & 158 & 1995년 \\
\hline 아동의 권리에 관한 협약(CRC, 아동권리협약) & 1989년/1990년 & 196 & 1991년 \\
\hline $\begin{array}{l}\text { 이주노동자와 가족의 권리보호에 관한 협약(MWC, 이 } \\
\text { 주노동자권리협약) }\end{array}$ & 1990년/2003년 & 48 & 미가입 \\
\hline 장애인 권리에 관한 협약(CRPD, 장애인 권리협약) & 2006년/2010년 & 160 & 2008년 \\
\hline $\begin{array}{l}\text { 강제실종자의 보호에 관한 협약(ICPPED, 강제실종철 } \\
\text { 폐협약) }\end{array}$ & 2006년/2010년 & 51 & 미가입 \\
\hline
\end{tabular}

제I장

국가들이 비준한 조약은 국가의 주인의식이 생긴다는 점과 이 조약들이 정부의 모든 기관에 걸쳐 법적 구속력이 발생한다는 점에 주목할 필요가 있다. 또한 인권과 관련된 국제회의에서 채택한 약속 역시 효력을 가질 수 있다. 우리나라는 헌법에 의거하여 헌법에 의해 체결, 공포된 조약과 일반적으로 승인된 국제법규는 국내법과 동일한 효력을 가진다. 개발 분야의 국제규범은 대체로 도덕적 정치적 구속력을 지니는데 반해 인권 분야의 국제규범은 법적 구속력을 지닌다. $\mathrm{MDGs}$ 처럼 개발 분야의 규범은 정책적 목표의 성격을 지니기에 재원의 여부와 정치적 의지의 정도에 따라 그 실현 여부가 좌우된다. 그러나 인권조약과 같은 규범은 각국의 정부와 국회의 비준 절차를 거치는 법적 성격을 지닌다. 따라서 인권기준과의 연계를 통해 개발 목표의 규범적 강제력을 강화할 수 있게 된다.

한편 국제사회는 어떤 특정 국가에 행동을 취함에 있어서, 그 국가가 인권적 의무를 위반하는 어떤 행동을 하도록 강요해서는 안 된다. 대신, 국제사회는 한 국가가 국제 조약상의 의무를

27) 외교부 홈페이지-주요 국제인권협약 가입현황은 아래에서 확인 가능하다. http://www.mofa.go.kr/webmodule/ htsboard/template/read/korboardread.jsp?typeID=6\&boardid=98\&seqno=326074\&c=\&t=\&pagenum=1\&t ableName=TYPE_DATABOARD\&pc $=\& \mathrm{dc}=\& \mathrm{wc}=\& \mathrm{lu}=\& \mathrm{vu}=\& \mathrm{iu}=\& \mathrm{du}=\quad$ (접속일: 2017.12 .05$)$ 
다하도록 가능한 모든 수단을 써서 도와주어야 한다. 빈곤 역시 인권의 문제이기 때문에, 이는 국제사회가 개별 국가의 빈곤 감소 전략 수립과 실행을 도와줄 수 있으며 동시에 그러한 역할을 해야 함을 의미한다. 예를 들어 무역과 투자에 관한 조약을 체결할 경우 기존의 인권조약의 의무 이행에 부정적인 영향을 미치는지에 대해 사전에 검토할 필요가 있다. 


\section{SDGs 이행과 인권기반접근(HRBA)}

한국의 경우 SDGs 이행은 국내이행과 국제이행 즉 개도국 이행 지원 두 과제를 동시에

수행해야 한다. 국내이행은 현재 환경부가 주무부처이고 지속가능발전 기본법에 의해 설립된 국가 지속가능발전위원회(National Council for Sustainable Development, NCSD)가 공식 적으로는 SDGs 국내 이행을 총괄한다.28)

환경부는 이미 20년 기한의「제 3 차 지속가능발전 기본계획(2016-2035)」을 채택하여 시행 하고 있는 중이다.29) 현재 지속가능발전 기본법 개정안이 국회에 상정되어 그 결과에 따라 현재의 환경부 산하 위원회가 대통령 또는 국무총리 산하로 승격될 가능성이 높다. 이후 2018년 에 2030년까지의 SDGs 국내이행 계획을 수립할 것으로 예상한다.

국제이행은 외교부가 주무부처이고 국제개발협력위원회가 전체를 총괄하고 있다.30) 유상원 조를 담당하는 수출입은행과 무상원조를 담당하는 KOICA가 시행기관으로 개도국의 이행지원을 담당하고 있다. KOICA는 이미 'SDGs 달성에 기여하는 개발협력 플랫폼'을 구호로 SDGs 달성 실행력 강화를 개도국 자립역량 제고, 개발협력 파트너 확대, 효율성 및 고객 중심 경영실천과 함께 4 개 전략목표의 하나로 채택하고 실행하고 있다. 그리고 중점 사업 분야로 교육, 보건의료, 공공행정, 농림수산, 기술환경에너지 및 범분야 6개 분야를 선정하여 역량을 집중하고 있다.31) 그리고 사업 분야에서 인권은 환경, 여성, 정보통신기술(Information and Communication Technology, ICT)와 함께 범분야 이슈로 추진되고 있다. 과거 3개년 「인권분야 전략(20132015)」을 작성했지만 구체적으로 실행되었다는 보고가 없고 현재 시행 중인 구체적인 실천전 략과 계획은 없는 상태이다.

지난 11 월 29 일 취임한 이미경 제 12 대 이사장은 취임사에서 7 개의 정책혁신과 경영혁신 방향을 제시하면서 여섯째로 평화, 민주주의, 인권, 성평등 등 인권의 핵심가치를 구현 하는 $\mathrm{ODA}$ 사업 개발 및 이행을 강조하였다. 동 취임사에서는 “기획과정에서 성과지표에 이르기까지

28) 국가 지속가능발전위원회에 대한 자세한 사항은 다음 홈페이지에서 확인 가능하다. http://ncsd.go.kr/app/sub01/ 11.do(접속일: 2017.12.05)

29) 환경부에 대한 자세한 사항은 다음 홈페이지에서 확인 가능하다. http://www.me.go.kr/home/web/policy_data/ read.do?menuId=10260\&seq=6664 (접속일: 2017.12.05)

30) 국제개발협력위원회에 대한 자세한 사항은 다음 홈페이지에서 확인 가능하다. http://www.odakorea.go.kr/ ODAPage_2012/T03/L01_S00_01.jsp (접속일: 2017.12.05)

31 한국국제협력단(KOICA)에 대한 자세한 사항은 다음 홈페이지에서 확인 가능하다. http://www.koica.go.kr/ (접속 일: 2017.12.05) 
$\mathrm{SDGs}$ 와의 정책적 연계성과 정합성을 검토하면서 $\mathrm{KOICA}$ 의 비교우위인 교육(SDG 4), 보건 의료(SDG 3), 물과 위생(SDG 6), 기아와 농업(SDG 2) 분야에 대한 전략적 지원에 집중”하고 “특히 SDG 16 번 목표 관련 평화와 민주주의, 인권의 핵심가치를 구현하는 ODA사업을 개발하 고 이행”할 것을 강조하였다.32) 아직 구체화되지는 않았지만 ODA 분야에 인권 주류화와 $\mathrm{HRBA}$ 이 체계적으로 반영될 것으로 기대된다.

기능적으로는 국내와 국제이행으로 나누어져 있지만 SDGs의 특성상 국내와 국제이행을 정책과 제도 일관성 (세부목표 17.14) 차원에서 유기적으로 연계하는 것이 중요하다.33) 위상이 강화되어 새롭게 출범할 것으로 기대되는 지속가능발전 위원회가 국제개발협력 위원회와 협력 하여 이 과제를 수행해야 한다.

SDGs 이행에서 유념해야 할 사항은 비록 SDGs가 수많은 이슈와 세부목표로 구성되어 있지만 국내와 국제사회의 중요한 도전과 문제를 모두 다루지 않는다는 사실이다. 예를 들어 동북아에서 가장 큰 현안이자 위협인 핵무기와 군사적 무기 감축 및 긴장 완화와 같은 안보문제, 원자력 발전소 안전 문제 등은 직접적으로 다루고 있지 않다. 보기에 따라서 또는 국가별 수준에 따라 SDGs의 내용은 달성하기에 너무 높은 최대치이거나 아니면 이미 달성한 최소치일 수도 있다. 따라서 SDGs의 원칙과 취지를 최대한 존중하면서 국가, 지역 또는 분야별 현실을 고려하 여 맥락적으로 재해석하고 이행할 필요가 있다. 따라서 SDGs는 명칭이 목표이지만 현실에서는 도구로 활용하는 접근법이 필요하다. 즉 SDGs를 체크리스트로 활용하여 지속가능발전 현황을 점검하고 공동의 대응책을 수립 실행하는데 유용한 도구로 활용하는 것이다.

SDGs 이행에 인권을 연계하는 방식은 크게 이행 단계, 목표 그리고 행위자로 구분할 수 있다. 이행단계는 SDGs 이행 제도화, 시행계획과 정책 그리고 모니터링과 평가 및 환류로 구분할 수 있다. 그리고 목표는 17 개 개별 목표에 따라 연계 할 수도 있고 사회발전(People), 경제개발(Prosperity), 지구환경(Planet), 거버넌스(Peace)와 이행수단(Partnership) 다섯 개의 분야로 묶어서 연계 또는 긴밀하게 상호연관된 목표와 세부목표를 묶어서 연계하는 방식도 있다. 행위자는 중앙정부와 국제기구 외에 주요그룹과 이해관계자에 따라 구분할 수 있다.

\section{1. 이행단계에 따른 인권 연계}

첫째, SDGs 이행 제도화 단계에서 정부 내 인권을 담당하는 부처와 기관의 참여가 중요하다.

32) 한국국제협력단 이미경 제 12 대 이사장 취임사는 한국국제협력단(KOICA) 공식홈페이지에서 확인가능하다. http://koica.go.kr (접속일: 2017.12.05)

33) SDG 17.14(정책 및 제도 일관성): 17.14. 지속가능발전을 위한 정책 일관성을 강화한다. 
국내에서 인권을 총괄하는 법무부와 인권외교를 담당하는 외교부, 그리고 국가인권위원회는 국 제인권기준의 국내이행과 이를 SDGs와 연계하는 차원에서 적극적 기여를 할 필요가 있다. 분야별 인권을 다루는 정부 각 부처도 인권의 관점에서 SDGs 제도화에 기여할 수 있어야 한다.

둘째, 시행계획과 정책 차원에서 한국정부의 NAP과 SDGs 국내 및 국제이행이 유기적으로 연계되어야 한다. 2007 년 처음 도입된 $\mathrm{NAP}$ 는 정부의 인권분야 종합 5 개년 계획으로 올해 제3차 NAP(2017-2021)를 채택할 예정이다.34) 인권 NAP는 UPR, 인권조약기구 및 특별절차 의 한국정부에 대한 권고안을 국내적으로 이행하는 종합 계획이다. NAP 주무부처인 법무부와 독립적인 국가인권위원회는 향후 한국정부의 SDGs 이행 계획수립과 이후 모니터링과 평가의 관점에서 적극적으로 기여해야 한다.

셋째, 모니터링과 평가 및 환류 단계에서 SDGs를 인권적으로 모니터하고 평가할 수 있도록 통계청과 협력하여 인권통계 기반을 구축하고 인권기반 모니터링 지표를 개발할 필요가 있다. 더 나아가 필요한 경우 특정 분야나 사업에 인권침해 예방과 효과성 증진을 위한 인권영향평가 를 실시 할 수 있어야 한다. 2012년 UN OHCHR이 개발한 인권지표35)와 국가인권위원회가 개발한 다양한 형태의 인권지표를 적극 활용할 필요가 있다. 2015년 10월 멕시코에서 열린 국가인권기구 세계총회는 SDGs 이행과 모니터링에서 국가인권기구의 역할을 강조한 메리다 선언(Merida Declaration)을 채택하였다.36)

넷째, SDGs 이행에 참여하는 모든 기관과 참여자를 대상으로 기본적인 인권교육이 체계적으 로 시행되어야 한다. 인권 감수성과 성평등 인식 제고를 위한 인권교육은 필수적으로 이루어져 야 하고 인권기반 개발협력사업 프로그래밍 등 직무 관련 인권교육과 훈련 또한 제공되어야 한다. 특히 국제개발협력 사업으로 개도국에 가는 사업수행자와 현지 사업 파트너 대상 인권교 육이 충실하게 이루어져야 한다.37) 이 과정에서 세계시민교육과 인권교육을 다루는 SDG 세부

34) 법무부 인권국에 대한 자세한 사항은 다음에서 확인가능하다. http://www.hr.go.kr/HP/COM/bbs_03/BoardList. do?strNbodCd=noti9006\&strNbodCdGbn=\&strType=\&strFilePath=hum/\&strRtnURL=HUM_5040\&str OrgGbnCd=110000 (접속일: 2017.12.05)

35) UN의 인권지표에 대한 자세한 사항은 다음에서 확인가능하다. http://www.ohchr.org/EN/Issues/Indicators/ Pages/HRIndicatorsIndex.aspx（접속일: 2017. 12.05）

36) 메리다 선언(Merida declaration)에 대한 자세한 사항은 다음에서 확인가능하다. https://nhri.ohchr.org/EN/ICC/ InternationalConference/12IC/Background\%20Information/Merida\%20Declaration\%20FINAL.pdf（접속 일: 2017.12.05)

37 ) 제 3 차 세계인권교육프로그램 (2015-2019)의 우선대상은 언론인이고 제1차(2005-2009)는 초등 및 중등학교, 2 차 (2010-2014)는 고등교육기관과 공무원, 특히 사법집행 공무원과 군인이었다. 자세한 사항은 다음 홈페이지에서 확인가능하다. http://www.ohchr.org/EN/Issues/Education/Training/WPHRE/ThirdPhase/Pages/ThirdPhase Index.aspx（접속일: 2017.12.05) 
목표 4.7과 역량강화를 다루는 세부목표 17.9 그리고 UN이 2005년부터 5년 단위로 시행하고 있는 세계인권교육프로그램(2015-2019) 연계하는 것도 중요하다.

\section{2. 목표에 따른 인권 연계}

목표별 인권 연계는 세부목표와 목표 그리고 5 개의 그룹 차원에서 연계하는 것 이외에 내용적 으로 긴밀히 연계된 목표와 세부목표를 묶어서 접근하는 방법도 중요하다.

첫째 세부목표와 목표 차원에서의 인권 연계이다. 이는 구체적으로 1948년 세계인권선언 이후 채택 시행해온 다양한 국제인권기준 - 조약과 선언, 원칙, 가이드라인 등 - 특히 9 대 조약 기구 위원회와 UPR의 국별 권고안, 그리고 UN HRC 인권 특별절차 보고관의 보고서와 권고안 을 목표와 세부목표와 연계하는 것이다.38)

둘째, 5 개의 그룹으로 인권과 연계하는 것은 개별 권리가 아니라 집단의 권리를 활용하는 것이다. 예를 들어 발전권39), 평화권40), 환경권, 민주주의에 대한 권리, 국제연대의 권리 등이 다.41) 이 중 대표적인 것이 2030 의제 곳곳에서 강조하고 있는 1986년 UN의 발전권 선언이다. 발전권 선언의 발전을 '포괄적인 경제적, 사회적, 문화적 그리고 정치적 과정'으로 정의한 발전 권 선언의 정신은 사실 2030 의제에 적절히 반영되어 있다. 그리고 발전을 평화 특히 군축과 연계한 통찰력은 한반도와 동아시아 현실에서 매주 중요하다.

셋째, 내용적으로 긴밀히 연계된 목표와 세부목표를 묶어서 접근하는 이른바 넥서스 접근이 있다. 예를 들어 UN 지속가능발전해법네트워크(Sustainable Development Solutions Network, $\mathrm{SDSN})$ 는 에너지(7번)와 물(6번)을 기후변화와 연계해서 접근하는 방식을 강조한다.42) 이 외에도 식량(2번), 건강(3번), 물(6번), 지속가능한 생산과 소비(12번)과 연계하는 방식도 있다.

38) 덴마크인권연구소 $\mathrm{SDG}$ 와 인권 연계 데이터베이스에 대한 자세한 사항은 다음 홈페이지에서 확인가능하다. $\mathrm{http}: / /$ sdg.humanrights.dk/ (접속일: 2017.12.05)

39) UN 발전권 선언에 대한 자세한 사항은 다음 홈페이지에서 확인가능하다. http://www.ohchr.org/Documents/ Issues/Development/DeclarationRightDevelopment_en.pdf (접속일: 2017.12.05)

40) UN 평화권 선언에 대한 자세한 사항은 다음 홈페이지에서 확인가능하다. http://www.ohchr.org//_layouts/15/ WopiFrame.aspx?sourcedoc=/Documents/HRBodies/HRCouncil/WGRightPeace/PresidentHRC_statem ent.doc\&action=default\&DefaultItemOpen=1（접속일: 2017.12.05)

41) 국제연대(International solidarity)의 권리에 대한 자세한 사항은 다음 홈페이지에서 확인가능하다. http://www.ohchr.org/ Documents/Issues/Solidarity/ProposedDraftDeclarationSolidarity.pdf (접속일: 2017.12.05)

42) 지속가능발전해법네트워크(SDSN)의 접근법에 대한 상세한 사항은 다음 홈페이지에서 확인가능하다. http://unsdsn.org/ resources/publications/sustainable-development-and-climate-change-practical-solutions-in-the-ener gy-water-nexus/ (접속일: 2017.12.05) 
이러한 접근법은 특정 사업이 다양한 목표에 어떻게 복합적으로 직간접, 단기 또는 장기적으로 기여하는지를 파악할 수 있다는 장점이 있다. 이를 통해 개별 목표에 파편적으로 접근하는 한계를 극복할 수 있다.

한편 넥서스 접근에서 실체적 목표인 1-15번 목표를 거버넌스(16번)과 이행수단(17번)과 연계하 는 것이 중요하다. 사실 16 번과 17 번 세무목표는 넥서스 접근이 반영되어 있다. 따라서 16 번의 다양한 세부목표와 17 번의 세부목표를 특정 목표와 목표 그룹과 연계하는 방식을 고려해볼 수 있다.

다섯째 인권 실현의 조건인 평화와 민주주의, 반부패와 투명성 등 인권기반 거버넌스 증진을 위한 체계적 노력이 강화되어야 한다. 평화, 인권, 민주주의 관련 세부목표로 구성된 16 번 목표 가 SDGs 체계 내에 독자적인 목표로 설정된 것은 민주적 거버넌스가 SDGs 효과적 이행의 전제이자 핵심요소라는 것을 의미한다. 16 번을 국내적으로 충실히 이행하면서 동시에 개도국 지원 사업에 전략적으로 활용하는 것이 필요하다. 즉 인권을 조건부 원조의 정치적 도구가 아닌 지속가능발전의 내재적 요소로 인식하는 것이다. 개도국의 인권 문제를 직접 다룰 경우에 발생할 수 있는 불필요한 정치적 논란을 사전에 예방하는 것이 중요하다. 따라서 16번 목표는 투명하며 효과적인 거버넌스를 구축하기 위해 정부, 시민사회 등 주요 행위자의 역량 강화(세부 목표 17.9) 이행과 연계해서 추진하는 것이 바람직하다.

이와 관련하여 한국의 지금까지의 경제사회발전 경험을 인권의 관점에서 비판적으로 재해석하고 인권친화적 지속가능발전 패러다임 제시하는 노력이 보다 적극적으로 이루어져야 한다. 논란이 되고 있는 '새마을 운동'을 인권과 국제개발협력의 기본 원칙에서 비판적으로 재평가하고 재구성 할 필요가 있다. 한편 16 번 목표를 매개로 하여 한국의 민주화 경험을 토대로 개발협력 파트너 국가의 민주화를 지원하는 프로그램을 개발하는 것도 중요한 과제이다. 이를 통해 한국의 빈곤퇴치, 경제발전, 민주화, 시민사회 성장을 분절화가 아닌 연계된 통합 프로그램으로 만들 필요가 있다.

\section{3. 이행 주체에 따른 인권 연계}

이행 주체별로 연계하는 것은 개별 주체에 따라 관련된 인권 기준과 제도를 연결하는 방식과 다양한 주체가 함께 협력하는 다자간 파트너십 등 두 가지 방식이 있다. 전자의 경우는 이른바 전통적인 주요그룹(major groups)과 이해관계자, 후자는 정부-민간-시민사회 파트너십 (세 부목표 17.17)이 있다.43)

43) 세부목표 17.17. 파트너십의 경험과 재원조달 전략을 바탕으로, 효과적인 공공·공공-민간·시민사회 파트너십 (Public, public-private and civil society partnerships, PPCP)을 장려하고 증진한다. 


\section{가. 다자간 이해관계자 파트너십}

1992년 리우 환경회의를 계기로 제도화된 주요 그룹은 다자간 이해관계자 파트너십의 핵심 이행주체이다. SDGs에서는 이를 정부-민간-시민사회 파트너십(PPCP)이라고 부른다.44) 인 권은 다양한 이행주체 모두가 준수해야 하는 규범이 되어야 한다. 주요 그룹은 크게 시민사회적 성격이 강한 여성, 노동자, 농민, 원주민, 아동과 청년 그리고 NGO 등 여섯 그룹과 기업, 지자체, 과학기술계로 나눌 수 있다. 이에 따라 구분해서 인권 연계 방식을 고려할 수 있다.

첫째, 시민사회에 속하는 6 개 주요그룹 구성원은 인권의 관점에서 인권옹호자라고 할 수 있다. 특히 옹호 및 대변 활동을 주로 하는 비정부기구는 가장 대표적인 인권옹호자라고 할 수 있다. UN은 세계인권선언 채택 50주년인 1998년 인권옹호자 선언을 채택하였고 이 선언의 이행을 촉진하고 모니터하고 특별보고관 제도를 2000년에 도입하였다. 각 그룹은 각각의 특성 에 따른 국제인권기준을 적용하고 관련 제도와 연계 할 수 있다.45)

둘째, 기업의 경우 2030 의제 제67항에46) 매우 구체적으로 준수해야 할 국제규범을 제시하고 있다. 이 중 2011년 UNGPs을 인권의 가치와 원칙에 부합하게 운영할 필요가 있다. UNGPs에 따르면 국가는 인권 보호의 의무를 기업은 인권을 존중하는 책무성을 지닌다. 이러한 원칙에 따라 UNGPs47)를 파트너십에 참여하는 모든 기업이 준수할 수 있도록 필요한 조치를 취할 필요가 있다.48) 현재 $\mathrm{KOICA}$ 주도로 2012년 부산 개발원조총회 이후 만들어진 다자간 개발협 력연대(Development Alliance Korea, DAK)에 참여하는 기관을 대상으로 기본적인 인권교 육 이 외에 이행지침에 대한 교육이 실시될 필요가 있다.49)

44) 과거에는 이러한 파트너십을 민관협력 (Public Private Partnership, PPP)이라고 불렀다. PPP는 시민사회가 없거나 Private의 일부로 포함되어 참여 주체와 역할에 대한 문제제기가 있어왔다.

45) 특별보고관 제도에 대한 자세한 사항은 다음에서 확인가능하다. http://www.ohchr.org/EN/Issues/SRHRDefenders/ Pages/SRHRDefendersIndex.aspx（접속일: 2017.12.05）

46) 2030 의제 항목 제 67 항: 민간기업 활동과 투자,혁신은 생산성, 포용적 경제성장 및 고용창출의 주요한 동력이다. 우리는 영세기업부터 협동조합.다국적기업에 이르는 민간 부문의 다양성을 인정한다. 우리는 모든 기업이 창의성과 혁신을 지속가능개발 과제의 해결에 적용할 것을 요구한다. 우리는 역동적이고 제대로 기능하는 기업 부문을 조성하 는 한편, 기업과 인권 이행 지침(UNGPs), 국제노동기구(ILO)의 노동기준, 아동권리협약(CRC) 및 주요 다자 환경 협정과 같은 관련 국제 기준·협정 및 이에 관한 기타 진행 중인 구상에 따라 당사국들의 노동권과 환경·보건 기준을 보호할 것이다.

47) UN 기업과 인권 이행원칙(UNGPs)에 대한 자세한 사항은 다음에서 확인가능하다. http://www.ohchr.org/ Documents/Publications/GuidingPrinciplesBusinessHR_EN.pdf (접속일: 2017.12.05)

48) 2030 의제 항목 제 67항: 민간기업 활동과 투자.혁신은 생산성, 포용적 경제성장 및 고용창출의 주요한 동력이다. 우리는 영세기업부터 협동조합.다국적기업에 이르는 민간 부문의 다양성을 인정한다. 우리는 모든 기업이 창의성과 혁신을 지속가능개발 과제의 해결에 적용할 것을 요구한다. 우리는 역동적이고 제대로 기능하는 기업 부문을 조성하는 한편, 기업과 인권 이행 지침(UNGPs), 국제노동기구(ILO)의 노동기준, 아동권리협약(CRC) 및 주요 다자 환경 협정과 같은 관련 국제 기준·협정 및 이에 관한 기타 진행 중인 구상에 따라 당사국들의 노동권과 환경·보건 기준을 보호할 것이다. 
섯째, 이와 관련하여 인권경영을 체계적으로 실천하는 노력이 시급히 이루어져야 한다. KOICA는 이미 개발협력 사업에 ‘인권존중과 사회적 가치를 구현하기 위해’ 인권경영 실천을 추진할 것을 공표하였다.50) 이에 이를 구체적으로 시행하는 종합 계획을 수립할 필요가 있다. 국제적으로 인권 경영은 보편적 규범으로 빠르게 확산되고 있다. 2016년 중국 항조우에서 열린 G20 정상회의는 SDGs 이행 관련 15개 지속가능발전섹터(Sustainable Development Sectors, SDS)를 채택 하여 중점적으로 이행하기로 했다(G20, 2016). 그리고 올해 7월 독일 함부르크에서 열린 G20 정상회의 선언문에는 책임 있는 공급망 관련하여 UNGPS와 OECD 다국적기업 가이드라인을 처음으로 포함하였다 $(\mathrm{G} 20,2017)$. 즉 주요 정치 경제 강대국의 모임인 G20은 SDGs와 기업과 인권을 의제로 채택하고 실행하기로 합의한 것이다. 국내에서 $\mathrm{KOICA}$ 와 유사한 업무를 수행하는 대한무역투자진흥공사(Korea Trade-Investment Promotion Agency, 이하 KOTRA)는 이 미 인권경영을 적극적으로 도입하였고 인권경영 연례 보고서를 발간하고 있다.51) 개도국의 $\mathrm{SDGs}$ 이행에 중요한 역할을 하는 KOICA, KOTRA 그리고 수출입은행 등 정부기관이 인권 경영의 적극적 선도적 실천을 통해 국제사회의 흐름에 적응 및 선도해나가는 노력이 필요하다.

넷째, 지자체의 국내에서는 지방 정부로 국가 행정체계의 일부이지만 $\mathrm{UN}$ 차원에서는 이해관 계자로서 주요 그룹의 지위를 지닌다. 지자체는 SDGs를 실질적으로 국내에서 실천하고 국민의 삶의 현장과 연계하는데 중추적 역할을 수행한다. 중앙정부가 SDGs 이행의 큰 정책 틀을 만든다면 이를 구체적으로 현실에서 실현하는 것은 지자체라고 할 수 있다. 따라서 지자체는 국내에서 하나의 이해관계자라기 보다 다양한 이해관계자들이 소통하고 협력하는 플랫폼을 제공하는 허브이자 거버넌스의 중추 역할을 수행해야 한다. 특히 지역 차원에서 SDGs를 다양 한 이해관계자와 파트너십을 통해 이행하고 이를 모니터링 및 평가하는 역할이 중요하다.52) 지자체와 인권의 경우 2011년부터 광주시가 주최한 세계인권도시포럼(World Human Rights Cities Forum, WHRCF)은 국제적으로 인권의 보호와 증진을 위한 지방정부 역할과 '인권도

49) KOICA 개발협력연대(DAK)에 대한 자세한 사항은 다음을 참조하기 바란다. http://www.koica.go.kr/program/ business/ngo/1317927_1796.html（접속일: 2017.12.05)

50) KOICA 보도자료 "KOICA, 개발협력 사업에 인권 존중과 사회적 가치 구현" (보도일쟈: 2017. 8. 17) http://www.koica. go.kr/pr/press/news/1324748_1756.html（접속일: 2017.12.05)

51) 대한무역투자진흥공사(KOTRA) 2016년 지속가능경영 \& 인권경영 보고서에 대한 자세한 사항은 다음을 참조하기 바란다. https://news.kotra.or.kr/user/reports/kotranews/20/usrReportsView.do?page=4\&reportsIdx=7875\& orderBy Type $=$ list\&searchStartDate $=\&$ searchEndDate $=\&$ searchReportGbn $=$ title\&searchText $=\&$ search AreaCd $=\&$ searchIndustryCateIdx $=\&$ CSRFToken $=$ cc7b01a0 - da97 $-452 \mathrm{e}-\mathrm{b} 86 \mathrm{f}-\mathrm{d} 46911 \mathrm{c} 11 \mathrm{f} 82$ (접속일: 2017.12.05)

52) 지자체의 역할에 대해서는 2030 의제 제 79항에 명시되어 있다. SDG 79: 우리는 또한 국가 주도이자 국가 중심으로, 국가 및 국가하위(지방) 수준의 진척을 정기적이고 포괄적으로 검토 할 것을 회원국에 권장한다. 이러한 검토는 국가적 상황, 정책 및 우선순위에 따라 선주민, 시민사회, 민간영역 및 다른 이해관계자들의 기여를 이끌어 내야 한다. 국회뿐 아니라 다른 기관들도 이러한 과정을 지원할 수 있다. 
시'의 확산에 중요한 역할을 수행해왔다.53) 특히 UN HRC 자문위원회가 준비하고 $\mathrm{HRC}$ 가 2015년 채택한 '지방정부와 인권(local government and human rights)' 보고서는 국제인권 의 국내화에서 지방정부의 중요성에 대한 인식을 확산하는데 중요한 역할을 하였다(UN, 2014). 최근 국내 및 국제적으로 지방 차원에서 SDGS에 대한 인권기반 접근 모색이 다양하게 이루어 지고 있다.

다섯째, 과학기술계와 직접적 연관되는 세부목표 17.6, 17.7 및 17.8이다.54) 2030의제 제 70 항에서는 과학기술혁신 촉진 그룹 결성과 포럼 개최를 소개하고 있다. MDGs에 비해 SDGs 의제가 다양화되고 복잡한 이슈들을 포괄하면서 과학기술의 역할이 매우 강조되고 있다. 특히 ICT의 역할에 대한 기대가 높다. 이러한 과학기술과 직접 연관된 국제인권기준이 명시적으로 있지 않지만 인권영향평가 등 실제적 측면에서 과학기술이 인권증진에 기여하는 방향으로 활용 될수록 모니터하는 역할이 중요하다.

〈표 11〉SDGs 이행 주요 그룹과 국제인권 규범 연계

\begin{tabular}{c|c|l}
\hline 주요 그룹 & 목표 (예시) & \multicolumn{1}{|c}{ 국제 인권기준과 의제 } \\
\hline 여성 Women & 5번 등 & 여성차별철폐협약(CEDAW, 1979) \\
\hline $\begin{array}{c}\text { 아동과 청년 } \\
\text { Children and Youth }\end{array}$ & 5번 등 & 아동권리협약(CRC, 1990) \\
\hline $\begin{array}{c}\text { 원주민 } \\
\text { Indigenous Peoples }\end{array}$ & 2번, 4번 등 & UN 원주민권리선언(UNDRIP, 2007) \\
\hline 농민 Farmers & 2번 등 & 농민의 권리 선언 초안55) \\
\hline $\begin{array}{c}\text { 노동자와 노동조합 } \\
\text { Workers and Trade Unions }\end{array}$ & 8번 등 & ILO 핵심노동기준 \\
\hline
\end{tabular}

53) 광주 세계인권도시포럼에 대한 자세한 사항은 다음 홈페이지를 참조하기 바란다. http://www.whrcf.org (접속일: 2017.12.05)

54) SDGs 중 기술 관련 세부목표(17.6, 17.7, 17.8)의 내용은 아래와 같다. 17.6 과학, 기술 및 혁신에 대한 남북·남남·삼 각협력 등의 지역 및 국가 간 협력과 접근을 강화하고, 글로벌 기술촉진 메커니즘 활용 및 특히 UN 차원에서 마련된 기존 메커니즘 간의 조정을 개선하여 상호 합의된 조건에 따른 지식공유를 확대한다. 17.7 상호합의에 의한 양허 및 특혜조건을 포함하여 개발도상국에게 유리한 조건으로 청정기술 및 친환경기술의 개발, 이전, 보급, 활용을 증진한 다. 17.8 2017년까지 최빈국을 위한 기술은행과 과학, 기술 및 혁신 역량강화 메커니즘을 완전히 운용하고, 특히 정보통신기술(ICT)과 같은 구현 기술의 활용을 강화한다.

55) UN 농민의 권리에 대한 선언(초안)에 대한 자세한 사항은 다음에서 확인 가능하다. http://www.ohchr.org/_layouts/15/ WopiFrame.aspx?sourcedoc=/Documents/HRBodies/HRCouncil/WGPleasants/Session3/Draft_Declarat ion_presented_by_Chair_EN.doc\&action=default\&DefaultItemOpen=1 (접속일: 2017.12.05) 


\begin{tabular}{c|c|c}
\hline 주요 그룹 & 목표 (예시) & \multicolumn{1}{|c}{ 국제 인권기준과 의제 } \\
\hline 비정부기구 (NGOs) & 모든 목표 & $\begin{array}{l}\text { 인권옹호자 선언(1998) } \\
\text { 인권옹호자 특별보고관(2000) }\end{array}$ \\
$\begin{array}{c}\text { 산업계와 기업 } \\
\text { Business and Industry }\end{array}$ & 9번 & $\begin{array}{l}\text { UN 기업과 인권 이행원칙(UNGPs, 2011) } \\
\text { OECD 다국적기업(MNE) 가이드라인 (2011) }\end{array}$ \\
\hline $\begin{array}{c}\text { 지자체 } \\
\text { Local authorities }\end{array}$ & 11 번 & 인권이사회 자문위원회 지방정부와 인권 보고서 \\
\hline $\begin{array}{c}\text { 과학 및 기술계 } \\
\text { Scientific and } \\
\text { Technological Community }\end{array}$ & 9번 & \\
\hline
\end{tabular}

출처: 고위급정치포럼(HLPF) 홈페이지 토대로 저자 재구성

개
발
협
력
이
슈
제파장




\section{Vl. 전망}

SDGs가 채택된 지 2년이 지났다. 한국은 SDGs 이행 원년인 2016년 초유의 탄핵사태와 촛불시민혁명 및 대선 등 국내 정치상황으로 이행계획을 세울 수 없는 상황이었다. 아쉽게도 문재인 정부의 100 대 국정과제에서 SDGs가 충분히 내용과 형식면에서 반영되지 못했다.

그러나 SDGs는 2030년까지 달성해야 하는 장기목표이기에 다소 늦었지만 지금이라도 중장 기목표와 체계적인 이행 계획을 수립해서 일관성 있게 추진해야 한다. 다행히도 문재인 정부가 내세운 주요 정책의 방향과 내용은 SDGs 정신과 상당히 부합하고 어떤 면에서는 SDGs보다 더 진일보한 것도 있다. 그러나 개도국을 지원하는 국제이행 분야에서는 과거에 비해 큰 질적 변화가 없어 보인다.

'새 술은 새 부대에 담아야 한다'는 말처럼 지금이라도 SDGs의 정신과 원칙에 따라 지금까지 한국의 국제개발협력 제도와 정책을 비판적으로 분석하고 쇄신할 필요가 있다. 문재인 정부 하에서 12 대 이사장을 새로 맞이한 $\mathrm{KOICA}$ 는 SDGs을 인권적으로 해석하고 인권기반접근을 효과적으로 적용한다면 SDGs가 한국의 국제개발협력의 분야 새로운 비전과 로드맵을 만드는 데 큰 기여를 할 것이다.56)

56) 상기와 관련하여 이미경 KOICA 12 대 이사장 취임사 (2017.11.29)에서의 아래 내용을 참고할 수있다. "문재인 정부의 외교정책 비전은 '평화, 민주주의 및 인권'을 핵심가치로 삼고, '국민외교, 공공외교, 협력외교' 전략을 통해, 한반도 평화와 통일의 기반을 조성하고, 책임있는 글로벌 중견국가로서 안보와 분쟁, 인권, 기후변화, 불평등 등 지구적 위기와 도전 해결에 적극적으로 참여하여, 보다 평등하고 민주적이며 평화로운 동북아시아와 글로벌 공동체 건설에 기여하고자 하는 것이라고 밝히고 있습니다." (http://www.koica.go.kr/koica_introduce/president/ announcement/1325421_3619.html)（접속일: 2017.12.05) 


\section{참고문헌}

한국국제협력단 보도자료. "KOICA, 개발협력 사업에 인권 존중과 사회적 가치 구현" （보도일자: 2017.8.17）（http://www.koica.go.kr/pr/press/news/1324748_1756. html) (접속일: 2017.12.05.).

한국국제협력단 ODA교육원. 2016. 『국제개발협력 심화편』. 성남: 시공미디어.

G20. 2016. "G20 Action Plan on the 2030 Agenda for Sustainable Development." G20 2016 China, available at http://www.g20.utoronto.ca/2016/g20-actionplan-on-2030-agenda.pdf (접속일: 2017.12.05.).

. 2017. "G20 Leaders' Declaration: Shaping an Interconnected World” G20 Hamburq Summit (2017.07.08 in Hamburq), available at http://www.g20. utoronto.ca/2017/2017-G20-leaders-declaration.html（접속일: 2017.12.05)

UN. 2003. "Statement of Common Understanding on Human Rights-Based Approaches to Development Cooperation and Programming." New York: United Nations.

. 2014. "24/2. Local government and human rights.” (A/HRC/RES/24/2). Geneva: United Nations.

. 2015. "Transforming our world: the 2030 Agenda for Sustainable Development (A/70/L.1).” New York: United Nations.

고위급정치포럼(HLPF): https://sustainabledevelopment.un.org/hlpf (접속일: 2017.12.05.). 광주 세계인권도시포럼 홈페이지: http://www.whrcf.org (접속일: 2017.12.05.). 국가 지속가능발전위원회 홈페이지: http://ncsd.go.kr/app/sub01/11.do (접속일: 2017.12.05.). 국제개발법기구(IDLO) 홈페이지: http://www.idlo.int (접속일: 2017.12.05.). 국제개발협력위원회 홈페이지: http://www.odakorea.go.kr/ODAPage_2012/T03/ L01_S00_01.jsp (접속일: 2017.12.05.). 덴마크인권연구소 홈페이지: http://sdg.humanrights.dk (접속일: 2017.12.05.). 법무부 인권국 홈페이지: http://www.hr.go.kr (접속일: 2017.12.05.). 베니스 위원회(Venice Commission) 홈페이지: http://www.venice.coe.int/webforms/ events (접속일: 2017.12.05.).

부산 글로벌파트너십(GPEDC) 홈페이지: http://effectivecooperation.org (접속일: 
2017.12.05.).

아디스아바바 행동계획(AAAA): https://www.un.org/esa/ffd/ffd3/index.html (접 속일: 2017.12.05.).

아태지역지식공유(KRE) 포럼 홈페이지: http://www.asiapacific.undp.org/content/ rbap/en/home/action2030.html (접속일: 2017.12.05.).

열린정부파트너십(OGP) 홈페이지: https://www.opengovpartnership.org (접속일: 2017.12.05.).

외교부 홈페이지: www.mofa.go.kr (접속일: 2017.12.05.).

$\mathrm{UN}$ 기후변화협약(UNFCCC) 제21차 당사국 회의: http://unfccc.int/meetings/paris_ nov_2015/session/9057.php (접속일: 2017.12.05.).

$\mathrm{UN}$ 인권최고대표사무소(OHCHR) 홈페이지: http://www.ohchr.org (접속일: 2017.12.05.).

$\mathrm{UN}$ 지속가능발전국제회의(UNCSD): https://sustainabledevelopment.un.org/rio20

(접속일: 2017.12.05.).

자발적국별보고(VNR): https://sustainabledevelopment.un.org/vnrs (접속일: 2017.12.05.). 지속가능개발목표(SDGs) 개별지표: https://unstats.un.org/sdgs/indicators/indicators-

list/ (접속일: 2017.12.05.).

지속가능개발목표(SDGs) 보고서: http://www.un.org/sustainabledevelopment/

blog/2017/07/pace- of-progress-must-accelerate-to-achieve-the- ${ }^{-}{ }^{-}{ }^{-}{ }^{-}$s $^{-}$

finds-latest-un-progress-report (접속일: 2017.12.05.).

지속가능발전해법네트워크(SDSN) 홈페이지: http://unsdsn.org/resources/publications/

sustainable-development-and-climate-change- ${ }^{-}$- ${ }^{-}$ractical-solutions-in-the

-energy-water-nexus/ (접속일: 2017.12.05.).

한국국제협력단(KOICA) 홈페이지: http://www.koica.go.kr (접속일: 2017.12.05.). 환경부 홈페이지: http://www.me.go.kr/home/web/policy_data/read.do?menuId= 10260\&seq=6664 (접속일: 2017.12.05.).

Post 2015 개발의제: https://sustainabledevelopment.un.org/post2015 (접속일: 2017.12.05.). 